\title{
ANAPHYLAXIS*
}

JOHN F. ANDERSON AND M. J. ROSENAL

WASHINGTON, D. C.

Anaphylaxis (ana, against, and phylax, guard, or phylaxis, protection), also called hypersusceptibility, supersensitiveness, is a condition of unusual or exaggerated susceptibility of the organism to foreign substances. The word "anaphylaxis" was introduced by Richet to describe a contrary condition to prophylaxis. As we now regard the phenomenon, the word is a misnomer, for we look upon the condition of hypersusceptibility as a distinct benefit and advantage to the organism. In fact, protection against a large class of infections depends on an altered power of reaction, $i$. $e$., hypersusceptibility or anaphylaxis.

This state may be congenital or acquired, and is specific in nature. The condition of anaphylaxis may be brought about by the introduction of any strange protein into the body. Hypersusceptibility to proteins that are non-poisonous in themselves may readily be induced in certain animals.

An animal may be in a condition of hypersusceptibility and immunity at the same time. The two conditions are closely interwoven; the latter is often dependent on the former. Von Pirquet advises that the term "immunity" be limited to indicate the condition of complete resistance in which no clinical reaction occurs, when poisons such as diphtheria, tetanus, etc., are introduced into the organism. $\mathrm{He}$ suggests the term "allergie" to indicate conditions of acquired immunity associated with anaphylaxis.

In the case of vaccinia the reaction to a primary "take" appears after an incubation period of four days. In a secondary vaccination the period of incubation is shortened and the clinical reaction lessened. In other words, the power of the organism to react has changed. This increased power of immediate reaction protects the individual. There is no absolute immunity in this class of diseases; the prophylaxis depends on the anaphylaxis.

Allergie then, as the word indicates (allos change, and ergon action), is an altered power of the organism to react. When this power of reaction is increased we say that the body is hypersensitive or in a state of anaphylaxis.

\footnotetext{
*Lecture delivered before the Harrey Society, December 5, 1908 .
} 
The tuberculin and mallein reactions are well-known instances of anaphylaxis. These substances are not poisonous when introduced into a healthy individual, but the tuberculous individual is anaphylactic to tuberculin, and an individual suffering with glanders is in a state of hypersusceptibility to mallein.

A clinical instance of anaphylaxis is the hypersusceptibility of some individuals to pollen-hay fever. The best studied instance of experimental anaphylaxis is that produced in the guinea-pig by the injection of a foreign protein; for example, horse serum, egg-white, bilk, etc. Especial study has been made of the anaphylactic action of the blood serum of the horse, partly because that serum is so much used in serum therapy.

It has long been known that the blood of certain animals is poisonous when transfused or injected into certain other species. Many instances might be cited showing that the blood serum of an animal of one species has poisonous properties when injected into an animal of another species. But the blood serum of the horse apparently lacks such poisonous action. Very large quantities of the blood serum of the horse may be injected into man, rabbits, guinea-pigs, and many other animals without serious inconvenience except occasionally a slight reaction at the site of inoculation.

In a certain proportion of cases the injection of horse serum into man is followed by urticarial eruptions, joint pains, fever, swelling of the lymph nodes, edema, and albuminuria. This reaction, which appears after an incubation period of eight to thirteen days, has been termed by Von Pirquet and Schick the "serum disease."

In exceptional cases, sudden death has followed an injection of horse serum in man.

We have shown that ordinarily horse serum is a comparatively bland and harmless substance when injected into certain animals; but these animals may be rendered so susceptible that an injection of horse serum may produce death or severe symptoms. For example, large quantities of horse serum may be injected subcutaneously, into the peritoneal cavity, into the brain, or directly into the circulation of a guinea-pig without apparently causing the animal the least inconvenience. If, however, a guinea-pig be injected with a small quantity, say 0.004 c.c., of horse serum and, after the expiration of a certain interval, again injected with horse serum the result will probably be fatal. The first injection of horse serum has sensitized the animal in such a way as to render it very susceptible to a second injection of horse serum. 
A certain time must elapse between the first and the second injections before the animal becomes susceptible to a second injection. This period of incubation is from seven to twelve days, and corresponds suggestively with the period of incubation of the serum disease, which von Pirquet and Schick place at eight to thirteen days.

Guinea-pigs may be sensitized with exceedingly small quantities of horse serum. In most of our work we used quantities less than 0.004 c.c., and we found in one instance that $0.000,001$ c.c. of horse serum was sufficient to render a guinea-pig susceptible.

Wells has recently shown that guinea-pigs may be sensitized with $0.000,000,05$ of a gram of egg albumin freed from the other proteins of egg-white.

It also requires very small quantities of horse serum, when given in a second injection, to produce poisonous symptoms. One-tenth of a cubic centimeter injected into the peritoneal cavity is sometimes suffcient to cause death; 0.1 c.c. subcutaneously may cause symptoms, while much smaller amounts given into the brain or directly into the circulation may be fatal.

At first we thought that diphtheria antitoxin had some relation to this phenomenon; we are now able to state positively that it has nothing whatever to do with the poisonous effects of horse serum; further, that diphtheria antitoxin in itself is absolutely harmless. The toxic action which we have studied is caused by a protein in normal horse serum and is entirely independent of the antitoxic properties of the serum.

\section{REVIEW OF LITERATURE}

Early in the last century Magendie ${ }^{92}$ found that rabbits which had tolerated two intravenous injections of egg albumin without any ill effects immediately succumbed to a further injection made after a number of days. Later, workers with precipitins have frequently found that some of their animals died suddenly during the course of treatment from no apparent cause, while what really happened was that they were in a state of anaphylaxis to the foreign proteid. Other analogous instances may be found scattered throughout the early literature.

In 1888 Arloing ${ }^{7}$ expressed the opinion that pathogenic microorganisms secrete soluble substances which influence the organism in such a way that at a later infection they succumb more quickly. The organism is robbed of its natural protecting bodies through the first process. Arloing evidently had in mind that the power of reaction of an organism could be changed. 
In 1891 Courmont $^{36}$ studied this question with reference to the tubercle bacillus and the subject was further pursued by the Lyons School with staphylococci, streptococci, B. pyocyaneus, and other bacteria.

Brieger, ${ }^{30}$ in 1895 , immunized a goat to a high degree against tetanus. The blood and milk of this animal contained large quantities of antitoxin. The animal, however, died of tetanus.

Knorr, ${ }^{82}$ in 1895 , studied this unexpected phenomenon more closely and found that guinea-pigs developed an increasing sensitiveness to tetanus toxin after repeated sublethal doses.

Uhlenhuth, ${ }^{148}$ in $189 \%$, worked on the relative toxicity of blood serum in health and disease. He found that intravenous injection into rabbits was not reliable and therefore used subcutaneous injections into guinea-pigs. He found that the normal sterile blood serum of man, sheep, hog, rabbit and cattle even in small doses (about 0.5 c.c.) produced infiltration in guinea-pigs when injected subcutaneously and necroses when given in large quantities. Twenty c.c. of these serums (10 to 15 of cattle serum) is sufficient to cause the death of guineapigs. Normal horse serum is not toxic, even in large doses (20 c.c.) ; at most it only produces slight infiltrations which are rapidly absorbed.

Hericourt and Richet, ${ }^{7 \pi}$ in 1898, in studying the effects of eel serum on dogs, found that they were not able to immunize them against the serum, but that on the contrary there was an increasing sensibility to it, so that finally the dogs died.

Courmont, ${ }^{37}$ in 1900 , found that a guinea-pig might support an intraperitoneal injection of a pleuritic effusion of about one-fifteenth its weight (30 c.c. for a 400 -gram guinea-pig), without fatal effect, whereas doses very much smaller (several c.c.) given in repeated injections under the skin or into the peritoneum caused edema and deatl.

Von Behring and Kitashima, ${ }^{153}$ in 1901, repeating some of Knorr's work, found a similar instance in a horse immunized against diphtheria. This curious phenomenon, sometimes seen with bacterial toxins, was called hypersusceptibility and was spoken of as a paradoxical reaction. Von Behring and Kitashima then made their experiments on guineapigs. Von Behring looked on the hypersusceptibility as purely histogenetic.

Portier and Richet, ${ }^{109}$ in 1902 , found that if dogs were given a very small dose of a glycerin extract from the tentacles of actinia, and then in fifteen or twenty days given a second small dose, the animals quickly succumbed. The dose given was so small as to cause no symptoms in a normal animal. They proposed the word "anaphylaxis" to indicate hypersensitiveness to a poison. 
Arthus, ${ }^{9}$ in 1903, studied the effect of repeated injections of horse serum on rabbits and found that if a rabbit were given repeated injections of horse serum at some days' interval it caused, even in small doses, results which, according to the number of the previous injections and methods of injection, were local or general, benign or grave.

Von Pirquet, ${ }^{167}$ in the end of 1902 , noticed that the symptoms following a second injection of horse serum in a child occurred on the same day and concluded therefrom that the current views on the period of incubation must be wrong. He believed that the organism must be changed through the production of antibodies and that the incubation period was the terminus of the production of these antibodies.

Von Pirquet and Schick, ${ }^{167_{-}{ }^{168}}$ in 1903, stated that an organism treated with a foreign serum was distinctly changed from one that had not been so treated. They believed that the strange serum did not work directly on the organism, but that there must be a reaction product or antibody. At the second injection the reaction might occur at once. This they called the "immediate" reaction. When the period of incubation was shortened they called it "accelerated" reaction. Von Pirquet and Schick found a number of analogies between these phenomena and the incubation periods of certain diseases, and mention specifically vaccination and the tuberculin reaction. Hypersusceptibility was shown in the case of injection with horse serum as well as tuberculin in those sensitized with tuberculosis.

1904

Wolff-Eisner, ${ }^{179}$ toward the end of 1904 , worked on the question of hypersusceptibility in the sense of Pfeiffer's endotoxins. From this starting point he handled the subject broadly and published his views. He studied the lysis of pigeon's blood corpuscles and human spermatozoa after the first and second injections into the peritoneal cavity of a guinea-pig. He observed that guinea-pigs always succumbed at subsequent injections. He explained this phenomenon on the ground that poisonous substances or endotoxins contained within the cells are freed when the cell membrane is dissolved. This solution is produced through a lysin formed by the previous treatment.

Detre-Deutsch, ${ }^{43}$ in 1904, studied the question why persons with syphilis do not show, on secondary inoculation, a primary lesion. $\mathrm{He}$ carried out experiments on guinea-pigs by reinfecting them with tuberculosis and showed the difference between the course of the first and the second injection, which he called "superinfection." His explana- 
tion of the acute action of the second injection coincides with Koch's addition theory of the tuberculin reaction.

1905

Richet, ${ }^{117}$ in studying two poisons (congestine and thalassin) extracted from actinia, found that if a very small dose, which caused practically no symptoms in a dog, was followed after twenty-two days by another small dose the animal became very sick or quickly died. He found that not only did his animals remain anaphylactic for a long time, but that it was necessary that a certain time elapse between the first and the second injections for the development of this increased susceptibility to the foreign protein. He further states that anaphylaxis is a new phenomenon which has never before been named or described, and that it is of the same order as that produced by the injection of tuberculin in an animal suffering from tuberculosis.

Von Pirquet and Schick, ${ }^{170}$ in a monograph on the serum disease, describe in detail this syndrome which sometimes follows injections of horse serum in man. They show that the symptoms of this disease when caused by a second injection may either appear at once (the immediate reaction) or after a shortened period of incubation (the accelerated reaction). From these clinical observations von Pirquet and Schick draw original and far-reaching conclusions. They show the relation of these clinical observations to the phenomenon of hypersusceptibility, and indicate the importance of these facts in general pathology. They draw attention to the analogy to the tuberculin reaction as a well-known instance of hypersusceptibility. Von Pirquet and Schick believe that the serum reactions give a possible explanation of the period of incubation of infectious diseases and finally conclude that the immunity caused by vaccinia and a group of infections is due to the power of immediate reaction acquired by the organism.

During Ehrlich's visit to America in 1904, Theobald Smith told him that guinea-pigs which had been used in testing the potency of diphtheria antitoxin became acutely sick or died from a subcutaneous injection several weeks later of several cubic centimeters of normal horse serum. Ehrlich gave the problem to Otto ${ }^{104}$, who worked out many cssential features of the phenomenon, to which he gave the name of the "Theobald Snith phenomenon."

Otto showed what is now well known to be the result of a second injection of horse serum into guinea-pigs. He demonstrated that the diphtheria poisons played no part in the phenomenon. He found, however, that guinea-pigs first treated with mixtures of diphtheria toxin 
and serum were more susceptible than those treated with serum alone. Otto showed further that immunity to the poisonous action of the serum injection might be acquired by repeated injections of large amounts of serum at short intervals. He demonstrates that this hypersusceptibility bears no relation to the specific precipitins. Finally, he discusses the relation of the Theobald Smith phenomenon to the cases of reinjection in man and cites instances of alarming symptoms following the second injection of antitoxic horse serum.

Pfeiffer ${ }^{108}$ confirmed Uhlenhuth's observations that certain sera, for example hog and sheep serum, caused gangrene of the skin and subcutaneous tissue when injected into a guinea-pig. On the other hand, the serum of horses and rabbits caused practically no reaction. Pfeiffer demonstrates that through repeated injections of normal serum it is possible to immunize the animals against this necrotic action and also that the serum of immunized animals is able to protect animals of the same species. He further confirms Uhlenhuth's explanation of the phenomenon by assuming that the serums contain a haptin in the sense of Ehrlich's side-chain theory. He believes the necrotic action to depend on and to be identical with hemolysis.

\section{6}

Rosenau and Anderson give the results of their studies, with special relation to anaphylaxis in guinea-pigs. They show that a single injection of horse serum is harmless for normal animals. Horse serum is, however, poisonous to a guinea-pig which has previously been injected with horse serum. The period of incubation was determined to be about ten days. The poisonous principle appears to act on the respiratory centers. The heart continues to beat after respiration ceases. It is shown that the toxic action of horse serum bears no relation to diphtheria. The poison is not toxin. Diphtheria antitoxin plays no part in this poisonous action and in itself is harmless. The effects of chemical, physical and electrical influences on the toxic and sensitizing principle are considered. It is shown that guinea-pigs remain susceptible a very long time and that very small quantities (in one instance $0.000,001$ c.c.) of horse serum are sufficient to render guinea-pigs susceptible.

It is shown that an active immunity against the toxic action of horse serum may readily be established by repeated injections of horse serum at short intervals into a guinea-pig. Rosenau and Anderson did not succeed in transferring this immunity in the blood serum or body juices to another guinea-pig. It therefore appears that the immune 
body, if one exist, against the toxic action of horse serum is not free in the blood or body juices.

It is shown experimentally that the guinea-pig may be sensitized by feeding with horse serum or with horse meat.

It is further shown that susceptibility to the toxic action of horse serum is transmitted from the mother guinea-pig to her young.

The specific nature of the phenomenon is shown. The opinion is expressed that the substance which sensitizes the animal is identical with that which later poisons it. The substance must, however, first cause a reaction in the organism, resulting in the production of antibodies. How man may be sensitized is considered in relation to the cases of collapse and sudden death following the injection of horse serum.

Anderson, ,2, 4 found that female guinea-pigs could transmit to the same offspring hypersusceptibility to horse serum and immunity to diphtheria toxin. This fact, Anderson states, is of great importance in testing antitoxic serums and necessitates care in the selection of breeders for guinea-pigs to be used in serum work.

Vaughan ${ }^{150}$ advanced the theory that the first injection of the strange proteid is broken up into components, one of which is toxic, but that the animal is not poisoned because this breaking up takes place slowly. The cells, however, learn from this lesson how to break up the complex molecule, so that when more of the strange proteid is introduced at the second injection it is violently rent asunder, quickly liberating large quantities of the toxic principle of the complex molecule.

MeClintock and King, ${ }^{95}$ as a result of their work, conclude that the sensitizing action of horse serum given by the mouth is not nearly so great as when given subcutaneously or intraperitoneally.

Remlinger ${ }^{113}$ found; in experiments on dogs, rabbits and guineapigs, an entire absence of anaphylaxis.

In his first series of experiments, he gave his animals normal horse or sheep serum or antidiphtheric or antitetanic serum; one month later, they received from 5 to 20 c.c. of a mixture of equal parts of antirabic sheep serum and emulsion of fixed virus.

In the second series of experiments, the animals were first treated with a mixture of fixed virus and antirabic sheep serum, and six or eight weeks later were given the serums above mentioned. None of the animals in either series showed any immediate symptoms, though two guinea-pigs and four rabbits died in five or six days. 
Thesc results, so contrary to all of the anaphylactic work, may be concerned, in part, with the question of specificity.

Von Pirquet ${ }^{157}$ explains the theoretical considerations of the accelerated reactions with special reference to vaccinia. The different characters of the areolas and the papular reactions are described and the conclusion drawn that vaccination does not cause an absolute immunity, but changes the power of reaction of the organism in such a way that it reacts sooner. Thus, when the organism is reinfected the process comes to a conclusion in a short time.

In a brief note von Pirquet ${ }^{155}$ suggests the name "allergie" (allos change, and ergon reaction) to indicate that condition of immunity achieved through an altered power of reaction. The close association between immunity and hypersusceptibility and the relation of these processes to the so-called endotoxins is discussed. Von Pirquet advises that the term "active immunity" should be limited to those conditions in which the introduction of a foreign substance into the organism causes no clinical reaction, that is, in which there is a complete lack of susceptibility. He discusses whether this is produced through alexins (natural immunity), through antitoxins (active or passive immunity against diphtheria and tetanus), or whether it is caused through a form of adaptation. (Wassermann and Citron.)

Von Pirquet ${ }^{156}$ concludes that the accelerated reaction in vaccinia is a specific reaction between the virus of cowpox and an immune or allergic organism. The accelerated reaction depends quantitatively upon the amount of the virus that is introduced. From the theoretical standpoint von Pirquet expresses the belief that the accelerated reaction is caused by the coming together of the vaccine virus with the antibodies in the allergic organism and that the precipitins are not concerned.

1907

Gay and Southard ${ }^{58}$ found in guinea-pigs dying from the second injection of serum and in those which had severe symptoms and were later chloroformed, what they considered characteristic lesions. Considerable hemorrhages, rather definitely localized, are the characteristic gross lesion. The hemorrhages may be in one or several organs, gastric hemorrhages being especially frequent. Microscopically, there are in addition to the naked-eye hemorrhages, minute, interstitial and oozing hemorrhages. They also claimed to have found fatty changes in voluntary muscle fiber, heart muscle fibers, and in nerve fibers.

Their explanation of serum anaphylaxis in the guinea-pig is substantially as follows: There is a substance in horse serum (anaphy. 
lactin) which is not absorbed by the guinea-pig tissue, is not neutralized, and is eliminated with great slowness from the body. When a guinea-pig is injected with a small amount of horse serum the greater part of its elements are quickly eliminated; the anaphylactin remains and acts as a constant irritant to the body cells, so that their activity for the other elements of horse serum is greatly increased. At the end of two weeks of constant stimulation by the anaphylactin a condition is arrived at in which, if the cells are suddenly presented with a large amount of horse serum they are overwhelmed in the exercise of their increased assimilating functions, and functional equilibrium is so disturbed that local or general death may occur.

In a second paper Otto ${ }^{105}$ demonstrated that guinea-pigs might be sensitized by injecting them with the blood serum of sensitized guineapigs, and further brought out the important point that guinea-pigs sensitized by such a transfer reacted within twenty-four hours. $\mathrm{He}$ believes that the first injection results in a weakening or depressing of the portions ("rests") of the antigens which are in the body and thus an apparent hypersusceptibility results. The duration of this hypersusceptibility depends on the amount of serum injected the first time.

Besredka and Steinhardt ${ }^{22}$ studied with much care certain features of hypersusceptibility to horse serum in guinea-pigs; they note that the French serums are much less toxic than those used by Otto in Frankfurt and the serums used by Rosenau and Anderson. Besredka and Steinhardt had a mortality of about 25 per cent. when 5 c.c. of serum were given intraperitoneally at the second injection, whereas death was the rule in our experiments under similar conditions. Most of their work was done with doses of 0.05 to 0.25 c.c., given directly into the brain, which either killed or caused grave symptoms in susceptible guinea-pigs. Besredka and Steinhardt lay stress on the production of "antianaphylaxis," which we termed "immunity." They found that a single injection of serum, given into the peritoneum of a sensitized guinea-pig, quickly conferred immunity to a subsequent injection of 0.25 c.c. into the brain; in one case the antianaphylaxis was present one and a half hours after the injection into the abdominal cavity. They were unable to demonstrate any protective properties in various organs of immune guinea-pigs.

Besredka and Steinhardt ${ }^{23}$ found that guinea-pigs could be put in a state of antianaphylaxis by the injection of horse serum into the brain as well as into the peritoneal carity. They consider it a phenomenon of the same order as the disintoxication in ritro of the tet- 
anized brain by antitetanic serum. They found that guinea-pigs could not be sensitized by intracerebral injection.

They think that their results seem to indicate that the phenomena of anaphylaxis and antianaphylaxis are similar to the precipating and absorbing actions which govern the relation of colloids among themselves.

Besredka ${ }^{15}$ concludes that the toxicity of therapeutic serums may be measured by means of intracerebral injections into sensitized guineapigs. Measured in this way, different serums show a wide range of toxicity, the fatal dose varying from $1 / 4$ to $1 / 128$ c.c. This toxicity resides in the serum and not in the cellular elements.

The serums of horses living under apparently the same conditions have about the same toxicity; individual variations are rare and of littie importance. The difference in the toxicity of serums appears to be due, in the first place, to their origin; and, in the second place, to their age. Serums are hypertoxic on the day of bleeding, and gradually lose their toxicity. This loss, rapid at first, becomes gradual after the tenth day. All therapeutic serums should be considered toxic within two months of bleeding. In a general way, all serums that excite grave anaphylactic phenomena in doses of 0.0625 to 0.05 c.c., and a fortiori, above this amount, should be considered toxic.

Besredka finally states that the technic and dosage by the intracerebral method is rapid, simple, and not expensive.

Besredka, ${ }^{19}$ in a preliminary note, states that serum heated to 100 C. has lost all of its toxicity for sensitive guinea-pigs, but still possesses some vaccinating properties; while serum heated to even $120 \mathrm{C}$. is still sensitizing. He believes there are two substances in horse serum: (a) the sensibilisinogene, which is thermostabile and gives birtl to the sensibilisine, which creates the anaphylactic state; (b) the antisensibilisine, which is thermolabile and, being an antibody, combines with the sensibilisine when the two come in contact. It is the sudden union of these two at the nucleus of the nerve cell which causes the symptoms of anaphylaxis, especially marked when the second injection is given into the brain.

Besredka ${ }^{16}$ considers that there may be two ways in which the toxic property of serum for sensitive guinea-pigs can be altered. These are directly on the serum, and indirectly on the animal itself. Of all the various direct means, such as chemical, phrsical or biologic, only heating the serum to high temperature is of avail. The toxic property is progressively decreased by heating from $76^{\circ} \mathrm{C}$. until at $100^{\circ} \mathrm{C}$. it disappears. He also finds that the immunizing power of the heated serum follows 
the same curve as the toxic property. The repeated heating of the serum three or four times at lower temperatures, such as $50^{\circ} \mathrm{C}$. or $60^{\circ} \mathrm{C}$. diminishes the toxic property three or four times.

As indirect means, he cites the use of serum as a preventive measure, cither during the preanaphylactic period or after the period of incubation. He states that ether narcosis prevents the appearance of anaphylactic symptoms, but that neither morphin nor extract of opium has any influence on the appearance of the symptoms.

In a further contribution to the subject Rosenau and Anderson ${ }^{130,131}$ studied particularly the relation of anaphylaxis to immunity. They express the opinion that profound chemical changes, perhaps in the central nervous system, are probably produced by the first injection of a strange protein. Many details concerning the sensitizing and toxic principle were studied. In addition to extending and confirming their work on the specific nature of the phenomenon they made further observations on the relation of various physical influences and chemical substances on the reaction. Among other things they brought out the fact that proteids extracted from the bacterial cells and injected into guinea-pigs produced, on the second injection, the same train of symptoms as in the case of serum anaphylaxis. It was found that in certain instances the hypersusceptibility manifesting itself from injections of these bacterial extracts left the animal immune to the corresponding infection.

Rosenau and Anderson ${ }^{132}$ later demonstrated the specific nature of anaphylaxis by showing that guinea-pigs may be in a condition of anaphylaxis to three protein substances at the same time. For instance, a guinea-pig may be sensitized with egg-white, milk, and horse serum and subsequently react in a brief period of time to a second injection of each one of these substances. It may be sensitized by giving these strange proteins either at the same or at different times, in the same or in different places, or by injecting them separately or mixed. The guinea-pig differentiates each anaphylactic-producing protein in a perfectly distinct and separate manner. The animal acts as though susceptible to three separate infectious diseases. The conclusion is therefore drawn that the phenomenon of anaphylaxis is specific and the belief expressed that the work indicates that chemical changes rather than morphologic alterations lie at the basis of this phenomenon.

Von Pirquet ${ }^{162}$ again clearly defines his conception of allergie and points out that a complete immunity does not exist. For example, in revaccination there is an immediate though slight clinical reaction and it is on this condition of hypersusceptibility that immunity depends. 
The convenience and advantages of the cutaneous vaccination for studying the problem and for diagnosis, especially in tuberculosis and other infectious diseases, are discussed.

Von Pirquet's ${ }^{163}$ admirable clinical studies on vaccination and vaccinal allergie are fully described by him in a brochure published in 190\%. The clinical side of primary vaccinations are first considered and then the clinical side of secondary vaccinations are pictured and discussed. He gives a clear picture of accelerated reaction in all its details largely by the use of curves and tables. Finally, von Pirquet's conception of allergie in relation to the early vaccinal reactions is explained. The theories of hypersusceptibility are fully discussed and their relation to the phenomenon of vaccination are considered. Von Pirquet concludes in part that these vaccinal characteristics were more or less known by the old vaccination physicians but, up to now, have been forgotten.

The new points discovered by von Pirquet are especially the morphological, the early reaction and the method of presenting them in curves. The observation that the normal time of reaction is gradually changed to the "immediate" reaction in secondary vaccinations is also new. Von Pirquet further brings forward his conception of the cachectic reaction and the differentiation between the papular and the areolar reactions. He insists on the presence of antibodies which lie at the foundation of accelerated reaction. An analysis of the local symptoms is divided into two processes: one, the growth of the infective principle; and second, the production of antibodies in the organism which explains the accelerated area-reaction.

Richet $^{122}$ gives a general review of the subject of anaphylaxis and also some very interesting work on anaphylaxis produced by a substance obtained from the Mytilus edulis. He found that the blood of a $\operatorname{dog}$ sensitized by this substance, when injected into an untreated dog, sensitized the animal two days later to an injection of the extract.

He thinks that anaphylaxis is due to the presence of a toxicogenic substance, non-toxic of itself, but producing a poison by reaction with the second injection of the extract. In support of this view, he states that a mixture of the serum of a sensitized dog and of the extract in vitro is more toxic than the extract alone.

Richet $^{120}$ reports further experiments on the production of anaphylaxis with an extract prepared from a mussel. (Mytilus edulis.)

The experiments were made on dogs, especial study being made of the production of romiting in the anaphylactic animal. 
Vaughan and Wheeler ${ }^{152}$ summarize their work to date on the poisonous and non-poisonous portions obtained by splitting proteins. They believe the poisonous group to be an essential constituent of all the protein molecules. It is the chemical nucleus and is regarded as a protein body the chemical structure of which remains unknown. It owes its poisonous action to the avidity with which it combines with certain groups in the molecules that constitute the cells of the respiratory center. The protein molecules of bacteria may thus be broken up, sensitizing the body. The poisonous group, when set free, induces the symptoms of disease and death. Protein susceptibility and immunity are different manifestations of one and the same process; both depend on the development in the animal body of a specific proteolytic ferment. They believe the non-poisonous portion of split proteins to be the immunizing or sensitizing haptophore. The sensitization results in the development of a specific proteolytic ferment. These reactions are specific. The development of a specific zymogen results from an alteration in the atomic arrangement within the protein molecules. Vaughan and Wheeler give a complete bibliography of the work of Vaughan and his pupils on this subject.

Currie $^{39}$ studied the effect of repeated injections of horse serum in persons admitted for treatment in the Glasgow Fever and Smallpox Hospital at Belvidere. He concludes that it is apparent from the facts detailed by him that repeated injections of horse serum induce symptoms of supersensitization in man, but it is also apparent that the same facts lend no countenance to the suggestion that the death of persons

- suffering from diphtheria is to be apprehended as the result of repeated injections of antidiphtheria serum.

Goodall ${ }^{64}$ gives observations on ninety patients who had received two injections of horse serum; of these, 43.4 per cent. gave either an immediate or accelerated reaction.

$\mathrm{Nicolle}^{100}$ found that guinea-pigs were not susceptible to the necrotic action induced by repeated injections of horse serum, as is the case in rabbits. He also found that daily injections or "spaced" injections, after the method of Arthus, did not induce a high degree of hypersensibility in guinea-pigs.

Bienenfeld ${ }^{25}$ has studied the leucocytes in the serum disease, and comes to the conclusion that the injection of large quantities of serum has a twofold effect on the number of leucocytes. Immediately following there is a leucopenia, and following this a leucocytosis. The bibliography contains fifty-two references to the literature on this phase of the subject alone. 
Friedemann and Isaacs ${ }^{55}$ report experiments on the metabolism of proteins introduced into the organism, through channels other than the gastrointestinal tract. The relation to immunity and hypersuseeptibility is discussed. Experiments on dogs and goats on nitrogen elimination, after the injection of homologous and heterologous serums, are considered. It is shown that dogs given intravenous injections of 40,80 , or 200 c.c. of egg-white soon die with characteristic symptoms including great muscular weakness and paralysis of respiration.

Heilner $^{\mathbf{7}}$ considers the effect of large amounts of foreign blood serums introduced into the body by the mouth or subcutaneously. $\mathrm{He}$ concludes that the introduction of such foreign serums, and also perhaps other proteins, into the circulation calls forth a certain effort which ordinarily is not present and, further, reports the fact that rabbits are able to withstand, without apparent harm, a single injection of very great quantities of foreign serums-as much as one-eighth of the body weight.

While studying the subject of anaphylaxis in Rio de Janeiro, Vasconcellos ${ }^{149}$ found that the guinea-pigs used in Rio, when given a sensitizing dose and, after the usual time, given a second injection, did not show any grave symptoms. He tested the Rio guinea-pigs with the Rio serum as well as with the serum from the Pasteur Institute at Paris, and from Nerck's and obtained similar results in each case.

In order to see whether this failure of the Rio guinea-pigs to show the reaction of hypersensibility was due to the race of the guinea-pigs, he obtained guinea-pigs from Argentina and found them very susceptible.

He considers that the race of the guinea-pigs plays a considerable rôle in the reaction to a second injection of horse serum.

Weil-Halle and Lemaire ${ }^{175}$ prepared an antiserum by injecting horse serum into rabbits and bled the animals when the horse serum as such has disappeared from the blood. Untreated guinea-pigs and rabbits were injected with varying amounts of this antiserum, under the skin of one thigh, and at the same time, with varying amounts of horse serum, under the skin of the opposite thigh. They found that varying with the proportion of the two serums injected, anaphylactic symptoms were produced, either local or general. When local symptoms were produced, they were always at the site of the injection of the antiserum. They believed that the intensity of the reaction seemed to depend on the relation between the quantities of the two serums; 
when the quantities approach unity the lesions are more local; when they are wide apart, the general symptoms are more common.

Remlinger, ${ }^{114}$ having found in previous experiments that he was unable to produce anaphylaxis in dogs, rabbits and guinea-pigs by the use of rabic virus and sheep serum, endeavored to determine whether this was peculiar to those substances, and if the same results would be obtained with antidiphtheria and antitetanus serums. With these serums, by repeated injections, he obtained no reaction in dogs. In rabbits and guinea-pigs, he obtained the local reactions and only exceptionally the general reactions.

When guinea-pigs and rabbits were given an injection of a mixture of serum and toxin and later injected with normal horse serum, some of the guinea-pigs showed symptoms.

Kinyoun $^{79 a}$ found that guinea-pigs sensitive to horse serum did not react if they were injected with the blood of a horse which had received several injections of human blood; but that the serum of a horse which had been rendered hemolytic for human red cells, was more toxic than normal serum.

He states that the toxic action is modified by the amount of the sensitizing dose so that the susceptibility is decreased as the amount of serum given at the first injection is increased until one-tenth of the body weight is reached, when they do not respond at all.

He also found that guinea-pigs which had been sensitized with serum did not react to milk.

\section{8.}

Lewis $^{88}$ considers that the incubation period of the hypersensitive reaction is not sharply limited, but that there is a progressive increase in sensitiveness from the sixth day, possibly before that, extending over a period of several weeks.

He confirmed our results as to the transmission of the hypersensitive reaction from mother to young, but found that all of the young of sensitive mothers were not equally sensitive. He considered that the anaphylactic state depended on the development of a special antibody during the incubation period, which may be transferred passively to an untreated animal. There is also in the serum of hypersensitire guinea-pigs an uneliminated horse serum element or "rest" which is distinct from the antibody. This antibody may be entirely neutralized by the gradual introduction in twenty-four hours of increasing doses of serum.

Lewis, ${ }^{89}$ in his second paper, reports studies chiefly on the hypersusceptibility of young guinea-pigs, born of treated mothers. He found 
that when the defibrinated blood of such young guinea-pigs was injected into untreated guinea-pigs, they were rendered hypersensitive to an injection of serum within a few hours, but if the injection of horse serum was delayed until after the incubation period, they failed to react. He discusses in some detail the mechanism of anaphylaxis, holding to the view that the sensitizing injection results in the formation of an antibody.

He also reports some work with a serum which had caused severe symptoms in a man about thirty minutes after injection. He did not find this serum materially different in toxicity from the various normal serums when tested on sensitive guinea-pigs.

By purifying horse serum with ether and then precipitating with ammonium sulphate, Gay and Southard ${ }^{57}$ found that, after several precipitations, the last fraction was as highly toxic as horse serum, but distinctly less sensitizing than either whole horse serum or the first fraction. The first fraction, obtained by one-third saturation with ammonium sulphate (euglobulins), is as highly sensitizing as whole horse serum; it is analogous to anaphylactin and apparently a purely sensitizing substance without admixture of the toxic elements of horse serum. This euglobulin is absolutely non-toxic for sensitive animals. Repeated large doses not only cause no refractory phase but shorten the period of incubation. It sensitizes normal animals in a few days (four or five).

Gay and Southard ${ }^{59}$ state that increased susceptibility in sensitized animals is due to the continued presence in the circulation of an unneutralized element of horse serum (anaphylactin), which acts as an irritant or stimulant to the body cells and in some way causes them to assimilate over-rapidly certain other elements of horse serum. They believe that anaphylactin is not an antibody to horse serum, but some retained substance. They also express the belief that the intoxication of animals by horse serum is not due to a toxic substance formed of antibodies plus antigen and that moreover the reaction of intoxication takes place, not in the circulation of the animal, but in the prepared cell.

Gay and Southard ${ }^{60}$ emphasize the point that a sensitive animal intoxicated with a large dose of serum and recovering passes thereby into a refractory state (antianaphylaxis), and by the same mechanism again becomes sensitive to the toxic effects of horse serum.

Gay and Southard ${ }^{61}$ state that animals sensitized with either eggwhite or milk will react more or less characteristically to horse serum. After sensitization with egg-white guinea-pigs will react faintly to 
milk; after sensitization to milk they will react slightly to egg-white. They conclude from this that anaphylaxis is only relatively specific.

Gay and Southard ${ }^{6 s}$ found macroscopic hemorrhages in one or more organs in 85 per cent. of the guinea-pigs which either died of $a$ second dose of horse serum or were killed within twenty-four hours after the second injection. The cause of death, when it occurs, is respiratory. Respiration ceases in the inspiratory phase and shows itself anatomically and histologically as emphysema. The most striking functional feature is severe diaphragmatic spasm. The application of horse serum to the exposed vagus of a sensitive guinea-pig produces severe respiratory symptoms. Gay and Southard regard the changes in the respiratory centers as a physical rather than as a chemical nature. They state that neither hemorrhage nor respiratory death is an indispensable feature of this disease. All guinea-pigs so far examined show fatty changes in many regions involving single muscle fibers or other cells.

Rosenau and Anderson ${ }^{6,136}$ report the results of further studies on anaphylaxis. It is shown that the period of incubation is about seren days in guinea-pigs sensitized in the brain and about nine dars in guinea-pigs sensitized subcutaneously. It also appears that the sensitization comes on somewhat gradually. The period of incubation is quite constant and is not appreciably prolonged by a large sensitizing dose. Sensitized guinea-pigs probably remain sensitive throughout the rest of their lives, at least 732 days.

The effect of heat and chemical substances is again studied in relation to the sensitizing and toxic principles in horse scrum. The specific nature of anaphylaxis is further shown by various experiments. Three separate anaphylactins have been demonstrated in the blood of a guinea-pig. It is shown that the substance known as anaphylactin is not present during the period of incubation; and may be demonstrated in the blood serum of immune guinea-pigs. Congestion and hemorrhages are sometimes found in guinea-pigs dead of anaphylaxis. Fattr lesions were not discovered. These morphologic alterations, it is belicres, to not explain the mechanism of anaphylaxis.

It is shown that horse serum used in cases followed by sudden death in man is no more toxic for guinea-pigs than antitoxic horse serum used extensively in human therapy without untoward symptoms. The belief is expressed that it is not the special toxicity of the horse serum, but the sensitization of the patient, which accounts for the collapse or sudden death sometimes following the injection of horse serum. The esscntial lesion in serum anaphylaxis is probably localized in 
Whe respiratory center, and the association of asthma with hypersusceptibility to horse serum must be considered in the use of antitoxin. A relation between the toxemias of pregnancy and anaphylaxis is suggested.

It is shown by Rosenau and Anderson ${ }^{135}$ that guinea-pigs can not be sensitized with guinea-pig fetal blood. Female guinea-pigs, however, may be sensitized with placental extract. After an interval of twenty-two days or longer they show symptoms of protein anaphylaxis when given a second injection of guinea-pig placental extract. It therefore seems that the mother guinea-pig may be sensitized with the autolytic products of her own placenta. These experiments suggest that there may be a certain relation between some cases of puerperal eclampsia and the phenomenon in the guinea-pig.

Besredka ${ }^{20}$ confirmed the results reported by Rosenau and Anderson, that guinea-pigs are easily sensitized to a second injection of milk. $\mathrm{He}$ found that they responded markedly to a second injection when given into the brain, and that guinea-pigs which had been injected with other substances than milk at the first injection, supported without ill effects an intracerebral injection of 0.25 c.c. of milk, thus showing the specificity of the reaction.

He found that when milk had undergone the lactic acid fermentation, the curd contained the sensitizing, as well as the toxic properties of the milk, while the whey (petit lait), even when given into the brain, failed to cause symptoms in a sensitive guinea-pig.

Besredka $^{21}$ refers to his preliminary note on the same subject in which he brings forth his ideas as to the presence in normal serum of the two substances, sensibilisinogéne and antisensibilisine and the properties and action of the two.

In his later article, he gives the details of his experiments on which he bases his conclusions. He belieres, as stated in his first paper on the same subject, that it is the combination of the sensibilisine and the antisensibilisine in the nucleus of the nerve cells that produce the anaphylactic shock. This shock may be lessened either by large doses given during the period of incubation, or by small repeated doses after the period of incubation, so that this union of the sensibitisine and antisensibilisine takes place more slowly.

The shock may also be lessened by rendering the nerre cells indifferent to this brusque union, as by ether narcosis. Antianaphylaxis is due to a descnsitization, followed by a return of the guinea-pig to a normal state. If the antianaphylaxis is not definite, following a large injection of the serum, it is because the surplus of sensibilisino- 
géne, which remains after the elimination of the antisensibilisine, is capable of resensitizing the inimal.

Wells ${ }^{1 i}$ suggests that the toxic effect of a second dose of protein injected into an animal that has been sensitized by an injection of the same protein two weeks or more previously, may be dependent on the aromatic radicals of the protein.

Wells ${ }^{178}$ in a most interesting article takes up a study of the chemistry of the substances involved in anaphylaxis and the chemistry of the reaction itself. The major portion of his work was with pure eggalbumin, purified by repeated crystallization. He found that this pure egg-albumin would sensitize guinea-pigs in doses of one-twenty-millionth of a gram; fatally, in doses of one-millionth of a gram. The minimum fatal dose for sensitized guinea-pigs, given intraperitoneally, was about 0.5 milligram, and about 0.1 to 0.05 milligram when injected into the circulation. As so small a quantity, 0.1 milligram, of pure egg-albumin is fatal for sensitized guinea-pigs, he thought it improbable that the injected protein itself could cause death by splitting up and liberating poisonous substance in the space of time in which the reaction occurs. He thought that the minuteness of the minimum sensitizing and intoxicating doses of pure egg-albumin seemed to indicate conclusively that, at least with this protein, both the sensitizing and intoxicating agents were one and the same kind of protein molecule, or else two different proteins of the same molecule.

$\mathrm{He}$ found that milk did not lose its sensitizing and intoxicating power when heated to 100 degrees for thirty minutes, and inclined to the belief that this might be due to the fact that the caseinogen of milk is not coagulated by boiling.

Iodization of serum and pure egg-albumin did not alter the specificity of the reaction when these substances were used on guinea-pigs.

Nicolle, Nicolle and Pozerski and Nicolle and Abt published three articles early in 1908 which may be reviewed together. ${ }^{102}$ We can not here follow these authors fully in detail and must satisfy ourselves with citing the principal points. The facts of protein hypersusceptibility are explained as follows:

The substance injected contains a toxic element which is set free by specific antibodies in the hypersusceptible animal. Hypersusceptibility may be produced by developing this antibody, to which the authors give the general name of lysin; thus, toxolysin, albuminolysin and cytolysin. They assume that a coagulation caused by another antibody is necessary. This antibody is called the coagulin; thus, toxocoagulin, albuminocoagulin, cytocoagulin. All the antigens produce antibodies 
at the same time. Depending on their respective quantities, there is either hypersusceptibility or immunity. The order of events following a reaction would be: First, the fixation of the antibody by the antigen, then the coagulation of the antigen, then the slow and silent destruction by the lysin.

These antibodies have not yet been demonstrated in vivo or in vitro; but the authors state that there is no reason why they may not exist as precipitins, acting only in vitro.

Hypersusceptibility occurs when there is a rapid lysis of a sufficient quantity of antigen. On the other hand, immunity manifests itself when there is first coagulation of the antigen. The lysis then follows slowly, liberating a little of the poison at a time. The two phenomena may coexist.

Otto $^{106}$ gives a comprehensive review of the work on anaphylaxis and the serum disease to date. He discusses the historical development of the subject,- the serum disease in man, experimental anaphylaxis especially in guinea-pigs, and concludes with an admirable review of the theories which have thus far been brought forward to explain hypersusceptibility. The bibliography contains seventy references to the literature on the subject.

Richet $^{124}$ in studying the anaphylactic properties of actino-congestine, suggests as a rational theory that the injection of the actinocongestine causes at the end of about two weeks (period of incubation) the formation of a new substance, which he calls toxogénine, which alone is harmless, but in the presence of the original poison becomes hypertoxic.

In this article he gives some interesting details of experiments on dogs, in which, by injecting untreated dogs with the serum of treated dogs, he was able to render the untreated animals very susceptible to a first injection of actino-congestine.

Hamman $^{72}$ states that the views of Wolff-Eisner seem to fit best into what we at present know of the tuberculin reaction and, shorm of their technicality, are briefly this: Tuberculin, which really consists of ultramicroscopic portions of the tubercle bacillus, produces the same effects in the animal body as the tubercle bacilli, except that the latter are capable of multiplication. The local tuberculin reaction is caused by an accumulation of lymphoid cells, and true giant cells are formed. The injection of living tubercle bacilli is followed by the derelopment of hypersensitireness the same as that which follows tuberculin injections. As in typhoid and cholera, the immunity reaction in tuberculosis depends on the presence of lysins. The tuberculin 
reaction is not due to the tuberculin itself nor to the disintegration at the site of disease, but to a new toxic substance formed by the action of the lysins on the albuminous portion of the bacillary body. For this toxic substance to become active the organism must be in a condition of hypersensitiveness. There are, then, two factors to be considered; the presence of lysins and the condition of hypersusceptibility. The lysins may be artificially increased and are the bodies which deviate complement in Wassermann's experiment. The hypersensitiveness raries under conditions of which we are still ignorant, but it, too, may to some extent be stimulated or blunted. Normally there is no lysin present, or so small an amount that when tuberculin is injected the transformation goes on so slowly that the newly formed toxin causes no appreciable effect. Under continuous minimal stimulation the quantity of lysin increases, and the transformation then occurs so rapidly that after injection intense toxic symptoms occur. The toxin causes a local reaction at the site of injection, constitutional symptoms and an infiammatory reaction at the site of the tuberculous lesion. During the inoculation of small doses of tuberculin hypersensitireness is dereloped. Tariation in susceptibility to tuberculin in tuberculous subjects depends essentially on variation in hypersensitiveness, lysins probably being present in all.

Weil-Halle and Lemaire ${ }^{1 \pi}$ found that if untreated guinea-pigs were injected at the same time with 0.01 c.c. of horse serum and 4 c.c. of the serum of a rabbit, which had previously been given horse serum, many of the guinea-pigs died in from eight to fifteen days. If the rabbit was bled in less than ten days or after sixty days, no ill effect was caused by the injections.

Remlinger ${ }^{115}$ having noticed that the injection of one large dose or sereral repeated small doses of the nervous tissue of the brain of different species produced in certain animals emaciation, cachexia and even death, endeavored to dotermine if this was due to an anaphylactic action of the nerve substance.

$\mathrm{He}$ injected dogs at intervals of ten to fifteen days subcutaneously with nerve tissue from the rabbit; guinea-pigs, with rabbit nerve tissue, and rabbits, with either rabbit, guinea-pig or dog nerve substance. Ifter a variable number of injections, they were all tested by the intracerebral injections of the nerre substance of the same species used in the preliminary treatment. He never noticed the least morbid phenomenon.

These results are open to the criticism that the use of several injections, especially in the guinea-pig, may hare immunized the animals to the test injection. 
Grunbaumis reports some observations in eleven cases in which antituberculosis serum had been administered. In no case did the second injection cause any uncomfortable effect; the fourth injection, in one case, was followed by an urticarial eruption; in another case, edema of the tongue and larynx followed two successive injections, and in a man thirty-one years of age, the twentieth injection was followed almost at once by cyanosis, vomiting, collapse and death in five minutes.

Grunbaum attributes these accidents to an individual susceptibility.

Banzhaf and Famulener ${ }^{12}$ found that anaphylactic symptonts could not be prevented by ether narcosis, morphin sulphate or calcium chlorid. They found that if chloral lyydrate was used to produce hypnosis in sensitive guinea-pigs, about 75 per cent. were completely protected against the injection intraperitoneally of 5 c.c. of serum, while 90 per cent. of the controls died.

Pozerski110 found that repeated injection of papain into guineapigs, very much less than the minimum lethal dose, at intervals of four or five days, produced after the third, fourth or fifth injection an undoubted state of anaphylaxis with death, accompanied by the same postmortem appearances as found in death from a single large dose.

Yoro $0^{96}$ assumes that the percutaneous reaction is a late reflex; that is, an angioneurotic inflammation. This view is confirmed by the fact that the reaction occurs at other points of the body than where the tuberculin lanolin is applied. The cutancous reaction is often symmetric and suggests, according to Moro, hypersusceptibility of the sympathetic nervous system.

Gillette $^{63}$ reports sudden death in an asthmatic following the injection, five minutes previously, of 2,000 units of diphtheria antitoxin. The postmortem failed to shed any light on the case.

SYMLTOMS CAUSED BY THE INJECTION OF HORSE SERUM INTO A SENSITIZED GUINEA-FIG

Very characteristic symptoms are produced by horse serum, either normal or antitoxic, when injected into a susceptible guinea-pig. The symptoms are apparently the same whether the injection is made subcutaneously or into the peritoneum, or whether normal or antitoxic serum is used. In five or ten minutes after injection the pig becomes restless and agitated; then manifests indications of peripheral irritation or respiratory embarrassment by scratching at the mouth, coughing, and sometimes by spasmodic, rapid or irregular breathing. This 
stage of exhilaration is soon followed by one of paresis or complete paralysis. The pig is unable to stand, or, if it attempts to move, falls on its side; when taken up it is limp. Spasmodic, jerky, and convulsive movements now supervene.

Pigs in this state with complete paralysis may fully recover; but usually convulsions appear, and are almost invariably forerunners of death. Symptoms appear in about ten minutes after the injection has been given; occasionally in pigs not very susceptible they are delayed thirty to forty-five minutes. Only in one or two instances of the many hundred pigs which we have observed have the symptoms developed after one hour. Pigs developing symptoms as late as this are not very susceptible and do not die. The chain of symptoms is exceedingly characteristic. The symptoms do not always follow in the order given. Death usually occurs within an hour and frequently in less than thirty minutes.

If the second injection be made directly into the brain the symptoms are manifested with explosive violence, the animal frequently. dying within two or three minutes. The same is also true if the second injection be made directly into the circulation.

We took the temperature of a number of guinea-pigs twice daily for eighteen days following the injection of large quantities of horse serum subcutaneously, in order to determine whether a febrile reaction followed. No marked deviation from the normal temperature was noted.

Normal horse serum, when injected into normal guinea-pigs, causes no symptoms. Large amounts, such as 6 or 10 c.c., may be injected into the peritoneal cavity of a guinea-pig without any apparent inconvenience to the animal. When normal horse serum is injected subcutaneously into the guinea-pig it is sometimes either absorbed very slowly or there is a slight local reaction, as indicated by edema and induration of the subcutaneous tissue at the site of inoculation.

THE POISON ACTS ON THE RESPIRATORY CENTER

Judging from the symptoms produced by the injection of horse serum into a susceptible guinea-pig we assumed that the poison acted on the central nervous system. Autopsies done immediately after the death of the guinea-pigs showed invariably that the heart continued to beat after respiration had ceased. In some instances the heart would continue to beat a full hour when exposed. This would seem to indicate that we were dealing with a poison which caused death through the nervous control of the respiration, and experiments show that this effect is certainly not local. 
PERIOD OF IXCUBATION

A certain time must elapse between the first and the second injection of the foreign protein before the toxic action is manifest. This period of incubation is from seven to twelve days and corresponds suggestively with the period of incubation of the serum disease, which von Pirquet and Schick place at eight to thirteen days, and with the period of incubation of some of the infectious diseases.

If a guinea-pig be given an injection of serum and then be injected again any time during the period of incubation no ill results follow. In other words, the animal has not had time to enter a state of anaphylaxis to the foreign protein. If, however, the injection be given after the seventh to the twelfth day the animal is then in a state of anaphylaxis or hypersusceptibility to the foreign protein. The animal remains suspectible a very long time. The longest period which we have observed is 732 days between the first and the second injection. There is no reason to doubt that guinea-pigs remain susceptible during their entire lives.

We found that the period of incubation appeared about the seventh day in guinea-pigs sensitized in the brain and about the ninth day in guinea-pigs sensitized subcutaneously. So far as may be judged, it therefore appears that the period of incubation is somewhat shorter in guinea-pigs sensitized in the brain than in those sensitized subcutaneously. It also seems quite evident that the sensitization comes on somewhat gradually. Judged by our results and the work of others the period of incubation is quite constant.

Lewis states that the period of incubation is not to be considered as abruptly terminating at a given day. He says that he has made an animal quite sick by the intracardial injection of 2 c.c. of serum on the sixth day after the toxin-antitoxin mixture. We have obtained suggestive symptoms on the fourth and the fifth day.

So far as may be judged from our work, the period of incubation is not appreciably prolonged by a large sensitizing dose.

THE SENSITIZING SUBSTANCE

We have suggested that the protein which sensitizes the guineapig is the same as that which later poisons it; profound changes are produced by the first injection. These changes localize themselves in the central nerve cells at the second injection. Our subsequent work has evolved nothing to alter this working hypothesis.

Guinea-pigs may be scnsitized by administering the foreign protein subcutaneously, intraperitoneally, intracerebraily, directly into the circulation, or by feeding. 
We have shown that the filtrate from horse serum, after precipitation with ammonium sulphate, still possesses sensitizing powers in spite of the fact that this filtrate contains but little of the serum globulin and is very weak in antitoxic value.

Formaldehyd does not appear to modify the sensitizing property in horse serum, though it is capable of destroying the toxic properties of tetanus ${ }^{5}$ and diphtheria toxins.

From a limited number of experiments it scems that the sensitizing principle is not dialyzable through a collodion sac when placed in the peritoneal cavity of a guinea-pig.

The sensitizing principle is not affected by the various preservatives used for the prescrvation of antitoxic serum, by drying, by precipitation with ammonium or magnesium sulphate, or by admixture with diphtheria or tetanus toxins.

The removal of the spleen or the thyroid from the animal before or after receiving the sensitizing dose apparently has no effect on the development of anaphylaxis.

We have found that the sensitizing principle of horse serum is gradually influenced by heat and almost entirely disappears when the liquid serum is heated to $100^{\circ} \mathrm{C}$. for one hour. Pigs sensitized with small quantities of horse serum heated to $100^{\circ} \mathrm{C}$. for one hour, when subsequently tested, develop very slight symptoms.

Guinea-pigs may readily be sensitized by intracerebral injections, provided quantities of 0.0001 c.c. or more are used. We obtained negative results with sensitizing doses of 0.00001 c.c.

The blood serum or an emulsion of the brain substance of a sensitized guinea-pig, when mixed with horse serum, does not modify the sensitizing power of the horse serum.

Some breeds of guinea-pigs appear to be more susceptible than others. The American guinea-pigs seem to be most susceptible, the German breeds not quite so much, and the French somewhat less, while the guinca-pigs tested by Vasconcellos in Rio de Janeiro scarcely respond at all.

THE TOXIC PRINCIPLE

At one time we made efforts to isolate the active principle in horse serum which causes the symptoms, but as soon as we realized that the toxic principle present in horse serum exerted its action in quantities so minute as to place it almost in the category with the ferments, we realized how difficult it would be, with the present technic, to isolate this substance. Nevertheless, we devoted much time and study to the relation of this toxic principle to rarions chemical, physical, and clec- 
trical influences. The practical importance of eliminating this toxic principle from horse serum, or of nentralizing it, is at once evident.

The toxic principle is not affected by various chemicals, such as calcium chlorid, sodium nitrate, magnesium sulphate, ammonium sulphate and formaldehyd..$^{5}$ It is not affected by various ferments, alkaloids and similar substances, such as takadiastase, pancreatin, rennin, myrosin, invertin, emulsin, pepsin in acid solution and in alkaline solution, ingluvin, malt, atropin, strychnin, morphin and caffein.

It is not affected by freezing at 15 degrees F., or by filtration through porcelain, drying, precipitation and dialysis, or exposure to the $x$-rays.

We found it interesting to compare the toxic effects on sensitive animals of untreated antitoxic serum, and the precipitated refined antitoxin; bulk for bulk we found them equally toxic. But as the same number of units can be given in half the bulk there is a manifest advantage in using the precipitated serum, as the rashes and other untoward effects of serum depend to some extent on the volume of serum administered.

The smallest amount of serum given intraperitoneally that we have found to cause the death of a guinea-pig is 0.1 c.c. One hundredth of a cubic centimeter, when given directly into the heart, is sufficient to cause the death of the animal, while 0.25 c.c. given into the brain is almost invariably fatal. In most of our work, however, we have used 5 or 6 c.c. of serum intraperitoneally, and this seems to be the farorite dose of other workers. Certain symptoms in guinea-pigs caused by a second injection of the serum suggested to us that the action might be due to hemolysis or the formation of precipitins. By a large number of cxperiments, however, we were able to exclude both hemolysis and the formation of precipitins as factors.

Sensitized animals were given various chemicals the day before the second injection of serum. No influence on the anaphylactic state was obtained by these substances. The following were used: pancreatin, potassium oxalate, sodium sulphate, magnesium sulphate, peptone, calcium chlorid and calcium acetate.

Obermayer and Pick find that when the aromatic radicals of a protein are combined with various substances the protein loses the power to produce precipitins of closely allied specificity for the original species. Their results suggest that the aromatic groups of the molecule are closely related to the species specificity. This indicates that the striking speciffcity of proteins of different species depends on the 
aromatic groups of the protein molecule and Vaughan has found evidence that the toxicity of the proteins depends on these same groups.

Fleischmann also finds that tryptic digestion destroys this characteristic species specificity.

We tested a large number of guinea-pigs to determine this point but found that, so far as the toxicity of horse serum is concerned at the second injection, it was not appreciably modified by iodin.

A few experiments were made to determine the relation of metahemoglobin-producing substances, such as nitrates, on the symptoms. Sensitive guinea-pigs were given subcutaneously an injection of sodium nitrite. In thirty minutes the exposed mucous membranes appeared distinctly blue; they were then tested for their susceptibility to horse serum and found to react in the usual way. Controls showed that the quantity of nitrite used was not sufficient in itself to kill the guineapigs.

Besredka reported some interesting observations concerning the prevention of anaphylaxis by ether narcosis. He stated that if sensitive guinea-pigs were etherized to the stage of complete relaxation and while in this state injected intracerebrally with normal horse serum, and the administration of ether continued a short time, the animal continued to sleep after the injection and at the end of about a half an hour awoke without presenting the least symptoms of anaphylaxis. If the guinea-pig were tested on the following day it would be found to be immune.

Of eight guinea-pigs on which we tried this experiment with ether, seven died from the effects of the second injection of horse serum. It is our belief that the guinea-pig which recovered had masked symptoms while under the influence of the ether and probably would not have died in any case, for we have a certain number of recoveries from the intracerebral injections of 0.2 c.c. of horse serum. It is true, however, that the narcosis masks the symptoms. The difference in our results may be accounted for either by the difference in toxicity of the French and the American serums, or, more likely, by the difference in susceptibility of the animals used.

Normal horse serum may be heated to 90 degrees C. for one hour and still remain slightly toxic when injected into a sensitized guineapig. Its toxicity, however, is evidently markedly affected. Heating to $\approx 0$ degrees $\mathrm{C}$. for one hour does not seem to diminish appreciably its poisonous properties, but it appears to be affected at 80 degrees $\mathrm{C}$. for one hour. At 100 degrees C. for one hour the toxicity apparently disappears. 
It appears that there is a slight difference between the sensitizing and toxic principles in horse serum so far as the resistance to heat is concerned. Serum heated to 100 degrees C. for one hour retains some power of sensitization, but seems to lose its toxicity when given at the second injection. This difference may be more apparent than real, for exceedingly minute amounts are sufficient to sensitize guineapigs, while a very large quantity of weakened serum would be necessary to produce symptoms. It must be remembered that in our experiments 20 c.c. of the dilution represents but 5 c.c. of serum.

These facts must be kept in mind when drawing conclusions from work on split proteins, fractional precipitation, or other methods to isolate the sensitizing substance in pure form. A very minute amount of the original protein substance in horse serum clinging to the globulin, or other substances modified by chemical methods, might be sufficient to sensitize guinea-pigs, whereas it would require very large amounts of such a modified protein to poison a sensitive animal.

\section{THE SPECIFIC NATURE OF ANAPHYLAXIS}

From our first studies upon hypersusceptibility we were interested in the question whether this reaction was specific.

In our first work on this subject we showed that this reaction was quantitatively specific for serums. That is, guinea-pigs sensitized with horse serum are subsequently very susceptible to a second injection of horse serum, but only slightly if at all susceptible to a second injection of the serum of other animals, such as rabbit, cat, dog, hog, sheep, chicken, or man. Conversely, guinea-pigs sensitized with the serum of these other animals are not very sensitive to a second injection of horse serum, whereas they respond actively to a subsequent injection of the same kind of serum as that used for the first injection.

We have further shown that the specific nature of this phenomenon is more marked when protein substances of widely different nature are used at the first and second injections. Thus, a guinea-pig sensitized with horse serum does not react at all to a subsequent injection of egg-white, vegetable protein, or milk. A guinea-pig sensitized with milk does not react to the other protein substances mentioned, etc.

We have succeeded in demonstrating more clearly the specific character of the phenomenon we are studying by proving that guinea-pigs may be in a condition of anaphylaxis to three protein substances at the same time. For instance, a guinea-pig may be sensitized with eggwhite, milk, and horse serum, and may subsequently react to a second injection of each of these substances within a brief period of time. The 
guinea-pig may be sensitized by injecting these strange proteins either at the same time or at different times, in the same place or in different places, or by injecting them separately or mixed. The guineapig differentiates each anaphylactic-producing protein in a perfectly distinct and separate manner. The animal is susceptible to the second injection of each one of the three substances in the same sense that it is susceptible to three separate diseases. These distinct reactions, in so brief a time, seem to accentuate the specific nature of the phenomenon we are studying. It also adds weight to our belief that profound chemical changes, probably in the central nervous system, rather than morphologic alterations explain the essential features of the reaction.

Further evidence on the specific nature of the phenomenon will be found in the discussion of anaphylactin.

\section{ANAPHILACTIN}

Gay and Southard first discorered the interesting fact that if the blood of a guinea-pig which has received a small sensitizing dose of normal horse serum be drawn, the serum collected, and 1.5 c.c. of this be given to a normal guinea-pig, the animal is rendered susceptible to a subsequent injection of horse serum fifteen days later.

Otto then showed that the animals react if tested within twentyfour lours.

Gay and Southard applied the name "anaphylactin" to this substance in the blood of sensitized guinea-pigs. They considered this substance a portion or "rest" of horse serum.

The sensitizing substance or anaphylactin (called sensibilisinogène by Besredka) is present in the blood serum of a sensitive animal. We have limited the word anaphylactin to indicate that substance in the blood serum of a sensitive animal which, when transferred into a normal animal, is capable of sensitizing it within forty-eight hours. It must be present in an exceedingly minute amount, for we have shown that the blood of guinea-pigs receiving only 0.002 c.c of serum contains this substance sereral months later, and 1.5 of the serum of such animal, when injected into a normal animal, renders it sensitive to a subsequent injection of horse serum twenty-four hours later.

It is of some interest to determine just when anaphylactin appears in the blood of a sensitized guinea-pig, particularly whether its prescnce may be demonstrated during the period of incubation. We found no indication of this substance in the blood of sensitized guinea-pigs until the ninth or tenth day, i. e., just about the time necessary to render guinea-pigs sensitive. 
We have found that anaphylactin is present in the blood serum of immune guinea-pigs. 'This fact is of importance in the consideration of the mechanism of anaphylaxis. From this we may argue that a true condition of immunity exists, for the sensitizing substance is certainly present in the flowing blood, but the organism as a whole or its susceptible cells are protected by a neutralizing antibody.

We have referred above to the fact that guinea-pigs may be in a condition of anaphylaxis to three protein substances at the same time. We later found that the substance in the blood serum of sensitized guinea-pigs known as anaphylactin is also specific in the same sense. By transfusing the blood serum of guinea-pigs sensitized to horse serum, egg-white, and milk, three separate and distinct reactions were obtained in the guinea-pig into which this serum was transferred.

LESIONS .

Gay and Southard, 190\%, found lesions in guinea-pigs dying from a second injection of serum, and in those which had severe symptoms and were later chloroformed, which they interpreted as explaining the mechanism of anaphylaxis. They state that, "the study of the histopathology of this serum disease shows us that we have to deal with an intimate cell reaction, demonstrable by definite cell lesions." These inrestigators state that considerable hemorrhages, rather definitely localized, are the characteristic gross lesions. The hemorrhages may be in one or several organs, gastric hemorrhages being especially frequent. Microscopically, there are, in addition to the naked-eye hemorrhages, minute interstitial and oozing hemorrhages. They also found fatty changes in voluntary muscle fiber, heart muscle fiber, and in nerve fiber.

That the congestion and dilatation of the blood vessels found in the abdominal cavity and the hemorrhages on the mucosa of the stomach are not characteristic of death due to anaphylaxis is evident from the fact that we have found that in violent death produced by large subcutaneous injections of chloral cyanhydrin or hydrocyanic acid there are somewhat similar congestions and hemorrhages. Further, we have lately had the opportunity to examine a guinea-pig whose death was caused by suffocation in an atmosphere of carbon dioxid. In the stomach and lungs of this guinea-pig lesions were found that, so far as the congestion and hemorrhages are concerned, were similar to those described in guinea-pigs dying from a second injection of horse serum.

We were especially struck by the fact that macroscopic congestions and hemorrhages were frequently absent in guinea-pigs poisoned by a second injection of horse serum given into the brain. 
Finally, this congestion and dilatation of the ressels of the abdominal cavity is well known to occur in shock and other states.

We were unable to confirm Gay and Sonthard's findings in regard to the fatty changes.

It is noticeable that one of the conspicuous lesions of the serum disease and other reactions to forejgn proteins consists of an angioneurotic edema. In scrum anaphylaxis as seen in the guinea-pig the irritation of the skin and mucous membranes of the mouth may be of the nature of an angioneurotic edema. One might imagine a localized edema of this character in the ganglia about the respiratory centers to account for the serious symptoms or death.

\section{FEEDING EXPERIMENTS}

Guinea-pigs may be sensitized by feeding them meat or serum.

We found that guinea-pigs could be sensitized by feeding them for some days on horse meat, or dried horse serum, mixed with their food. We did not use a stomach-tube, as the possibility of making slight wounds in the esophageal or gastric mucosa would vitiate the feeding experiments, as we know from our previous work that very small quantitics could readily sensitize the animal to a subsequent injection of serum.

The guinea-pigs that had been fed with horse meat or horse serum, after an interval of at least four days, were injected with horse serum and reacted in a characteristic manner.

We also found that guinea-pigs could be sensitized to cattle serum by feeding them with beef. Cooking the meat entirely destroyed its sensitizing properties.

The fact that guinea-pigs may be rendered susceptible by the feeding of strange protein matter opens an interesting question as to whether sensitive guinea-pigs may also be poisoned by feeding with the same serum given after a proper interval of time. If man can be sensitized in a similar way by the eating of certain protein substances, may not this throw light on those interesting and obscure cases in which the eating of fish, sea food, and other articles of diet habitually cause sudden and sometimes serious symptoms?

\section{MATERNAL TRANSMISSION}

In the course of our work we had the opportunity to test the susceptibility of the young of susceptible guinea-pigs and we found that hypersusceptibility to the toxic action of horse serum is transmitted from the mother guinea-pig to her young. This function is solely maternal; 
the male takes no part whatever in the transmission of these acquired properties. Whether this maternal transmission is hereditary or congenital can not be definitely stated.

We were able to exclude the milk as a factor in transmitting the hypersusceptibility to the toxic action of horse serum by a series of "exchange" experiments. Exchange experiments consist in at once placing guinea-pigs born of a susceptible mother to nurse with an untreated female while, in exchange, the young of the untreated female are placed to nurse with the susceptible female. From these exchange experiments we learn that the hypersusceptibility is not transmitted to the young in the milk.

We also learned from our experiments that hypersusceptibility may be transmitted from mother to young, whether the mother is sensitized before or after conception.

If an anaphylactic tendency be transmitted from mother to young in man it may explain the severe reaction and death that occasionally take place following a first injection of serum.

These results on the hereditary transmission of the susceptibility to the poisonous action of horse serum in guinea-pigs may throw light on the well-known inherited tendency to tubereulosis in children born of a tuberculous parent.

There are certain analogies between the action of tuberculosis and horse scrum. Both produce hypersensitiveness and also a certain degree of immunity. Now that we have proved that this hypersensitiveness or anaphylactic action in the case of horse scrum may be transmitted hereditarily in guinea-pigs, may it not throw light upon the fact that tuberculosis "runs in families"? While there are several recorded instances demonstrating that immunity to certain infectious diseases may be transmitted from a mother to her young, this is, so far as we know, the first recorded instance in which hypersensitiveness, or a tendency to a discase, has been cxperimentally shown to be transmitted from a mother to her young.

IMMUNITY TO ANAPHYLAXIS

We showed in our first publication on the subject of anaphylaxis that guinea-pigs may be actively immunized against this phenomenon. At the same time we demonstrated that the immunity could not be transferred passively to other animals in the blood or body juices.

Guinea-pigs may be actively immunized in several ways: (1) by repeated injections of serum during the period of incubation, i. e., during the first ten days, before the animal reaches the state of hyper- 
susceptibility; (2) animals that recorer from a second injection giren during the anaphylactic stage are at once immune.

The fact that guinea-pigs can not be immunized passively by the transfer of blood or body juices would make it appear that the "immune body," if such exists against the toxic action of horse serum, is not free in the blood or body juices as is the case in diphtheria. In fact, it has been questioned whether the active immunity which we have described is an instance of true immunity, or a "refractory" condition, or even an actual return to the normal.

Subsequent researches have strengthened our belief that we are dealing with a true condition of immunity and not a prolongation of the period of incubation or a return to the normal. Thus, it has been shown that guinea-pigs in the "refractory" condition still contain anaphylactin in their blood. It is at once evident that they hare not returned to their normal condition. Further, we have demonstrated that such "refractory" female guinea-pigs will transmit this anaphylactic substance to their young. Only the sensitizing substance passes into the blood of the fetus, which is therefore in a condition of hypersensibility. The "immunizing substance" or "condition" is not transmitted.

It seems to us that we have here a striking analogy to that phase or lind of immunity which ron Pirquet describes as "allergie." In other words, we have an acquired immunity associated with anaphylaxis. In guinea-pigs this immunity may follow one attack of the disease, i. e., the serum reaction. As stated by von Pirquet, "allergie" manifests itself by an immediate reaction and corresponds to the condition of immunity conferred by an attack of smallpox or some of the other acute infectious processes.

In the case of syphilis we have a striking instance in which the rirus is not autoinoculable. In the serum reaction in the guinea-pig an analogous train of events occurs, for after the sensitized guineapig has responded the reaction renders the organism immune.

ACTION OF HORSE SERLII ON MAN AND OTHER ANMMALS

It may be that man can not be sensitized in the same way that, as we have shown, guinea-pigs can. We made no human experiments, but experimental data are recorded by others which have a direct bearing on this question.

Repeated injections of horse serum into man is not an infrequent occurrence. Patients suffering from diphtheria are often given injections of antitoxic serum at short and frequent interrals. It is also 
not rare for persons to have several attacks of diphtheria at long intervals and to be treated each time with antidiphtheria serum.

Certain serums, for example the antitubercle serum of Maragliano or the antirheumatic serum of Menzer, are habitually used by injections at intervals of days or weeks.

In all these cases of frequent or repeated injections the amount which has been injected and the interval between the injections must be taken into account in relation to this work. Von Pirquet and Schick, in their work on Serumbrankheit, give eight instances in which children received two injections of horse serum at intervals of sixteen to forty-two days between the first and the second injections. All these eight cases show this in common, that after the first injection of horse serum the symptoms of the serum disease appear after the normal period of incubation, i. e., between the eighth and the thirteenth day. But when the individuals are again injected with horse serum after intervals of sixteen to forty-two days symptoms of the serum disease reappear at once or at least within twenty-four hours.

Von Pirquet and Schick give a list of 60 children who were injected with antitoxic horse scrum at intervals of six days to seven and a half years between the first and the second injections. They found that when the second injection was given from fourteen days to four months after the first injection they obtained, with great regularity, what they termed the "immediate reaction"; but when the interral between the first and second injections is over four months they obtained little or no immediate reaction but what they termed "an accelerated reaction," for the fever, urticaria and other symptoms of the discase appeared on the fifth, sixth, seventh, or eighth day. It will be remembered that the normal period of incubation for the symptoms of the serum disease to appear after the first injection is between the eighth and the thirteenth day. Von Pirquet and Schick lay special stress on the phenomenon of the "immediate" and the "accelerated" reactions following the second injection.

We might also conclude, despite the suggestion in our work on sensitizing guinea-pigs by feeding them with horse serum or horse meat, that children are not sensitized to the toxic action in horse serum by eating horse meat, from the fact that horse meat is a favorite article of diet in certain European countries, and that there is nothing on record to show that the injection of horse serum in those countries is fraught with more danger than where this practice does not obtain. We must, however, remember that our work has shown that guinea-pigs are scnsitized with exceedingly minute quantities of the strange 
protein, and that repeated injections cause an immunity; and it is possible that the same may be true of feeding. Further, we have shown that cooking destroys the sensitizing property of meat.

Man reacts to the first injection of horse serum after a period of incubation of eight to thirteen days. Guinea-pigs show practically no reaction following the first injection. Both react to a second injection. The reactions in man and the guinea-pig, however, differ both in severity and in kind. The relation, therefore, that our observations on the guinea-pig may have in its application to man must await further study. Of course, the fact that other animals beside man and guineapigs react to a second injection of horse serum would seem to indicate that we are dealing with one and the same reaction.

It has been shown that rabbits react after repeated injections, which has also been noted in the use of repented injections of the serum in man.

THE RELATION OF SERUM ANAPHYLAXIS IN TIIE GLINEA-PIG TO SERUM THERAPY

Besredka and Steinhardt were the first to point out that the second injection may be given into the brain of guinea-pigs. When a small quantity of horse serum is injected into the brain of a sensitized guinea-pig the symptoms appear promptly and often with great violence, and death is a common result.

Besredka believes that intracerebral injections may be used as a measure of the toxicity of therapentic serums. He states that, measured in this way, different serums show a wide gamut of toxicity, the fatal dose varying from $1 /{ }_{4}$ to $1 /{ }_{12 s}$ of a cubic centimeter. He believes that this toxicity resides in the serum and not in the cellular elements; further, that the serum of horses living under apparently the same conditions has about the same toxicity, individual variations being rare and of little importance. He concludes that, in a general way, all serums which ineite in guinea-pigs grave anaphylactic phenomena in doses of 0.0625 to 0.05 c.c. and a priori above this amount should be considered toxic.

We doubt whether there is a relation between the toxicity of serurns as tested on guinca-pigs in this way and their power to produce the serum disease or collapse or sudden death in man. It appears to us that in man the symptoms of the serum disease depend partly on the kind of serum and the amount used. The unfortunate accidents, such as collapse and sudden death, depend more on the sensitization of the individual than on the so-called toxicity of the serum used. 
Fortunately, we were able to obtain two antidiphtheria serums which had been used in two cases followed by sudden death:

CASE 1.-Serum No. 2277. Reported by Dr. S. N. Wiley, Norristown, Pa., (Jour. Am. Med. Assn., 1908, i, 137). Mr. E. W., aged 34 years, splendid physique, best of health. Prophylactic injection of 1,000 units antidiphtheric serum. Site of inoculation four inclıes above Poupart's ligament. Within two minutes had violent symptoms-anxious expression, itching, burning, labored breathing; lips, face and neck swollen and red; paralysis; convulsions. Died witlin five minutes of injection.

C.ASE 2.-Serum No. 2295. Reported by Dr. H. F. Gillette, Cuba, N. Y., (Jour. Am. Med. Assn., 1908, i, 40). Mr. B., 52 years old. Had asthma and bronchial catarrh. Urine and heart normal. Rheumatic attack fifteen years ago. Coughed and raised plenty of sputum. Injection of 2,000 units antitoxic serum under left scapula. Prickling sensation in neck and chest, labored breathing, pulse regular and full. Seized with tonic spasm. Died within five minutes after injection.

From our experiments it is plain that the serums which do not produce untoward symptoms when injected into man are quite as toxic on sensitized guinea-pigs as the serums which have been followed by serious symptoms when injected into man. We believe that the difference lies in the susceptibility of the individual and not in the toxicity of the serum.

It has interested us very much to find that the above two cases, and also others that have come to our notice, were in asthmatics. In our first publication we suggested that the essential lesion of serum anaphylaxis is probably localized in the respiratory center, and the association of asthma and hypersusceptibility to horse serum in man would seem to lend weight to this hypothesis. The knowledge of the fact that the injection of horse serum into some asthmatics is attended with danger must be considered in the use of antitoxin.

\section{FYPERSUSCEPTIBILITY ANI IMMUNITY PRODUCED BY BACTERIAL PROTEINS}

We believe that the problem of hypersusceptibility has an important bearing on the question of immunity and hence we have expressed the opinion that "resistance to disease may largely be gained through a process of hypersusceptibility. Whether this increased susceptibility is an essential element or only one stage in the process of resistance to discase must now engage our attention." We can not escape the conviction that this phenomenon of hypersusceptibility has an important bearing on the prevention and cure of certain infectious processes. Our work on the hypersusceptibility produced by the bacterial proteins strengthens this belief, for our recent results prove that the phenomenon 
of hypersusceptibility to certain proteid substances extracted from the bacterial cell is followed by a definite immunity against infection by the corresponding micro-organism.

Experimental study of the bacterial proteins is of the greatest importance on account of the practical uses to which results along this line may lead. The relation of these studies to the so-called endotoxins is evident.

Hypersusceptibility may easily be induced in guinea-pigs with protein extracts obtained from the bacterial cell. The first injection of most of the extracts used by us seems comparatively harmless to the animal. A second injection of the same cxtract shows, however, that profound physiologic changes have taken place. A definite period must elapse between the first and the second injection. The symptoms presented by the guinea-pigs as a result of the second injection resemble those caused by horse serum. The phenomenon induced by a second injection is followed (in certain cases) by an immunity to the corresponding infection.

These results strengthen our belief that the phenomenon of hypersusceptibility has a practical significance in the prevention and cure of certain infectious processes. It also gives a possible explanation of the period of incubation of some of the communicable diseases. Is it a coincidence that the period of incubation of a number of infectious discases is about ten to fourteen days, which corresponds significantly with the time requircd to sensitize animals with a strange protein?

In certain infectious diseases with short periods of incubation, such as pneumonia, the crisis which commonly appears about the tenth day may find a somewhat similar explanation. It is evident that disease processes produced by soluble toxins, such as diphtheria and tetanus, do not belong to the category now under consideration.

The hypersusceptibility produced by the colon and typhoid bacilli was followed by a definite immunity to the corresponding infection. In case of anthrax, however, immunity does not follow hypersusceptibility to the anthrax protein. We are not dealing, therefore, with a general law applicable to all infections, but with certain limitations, as in the case of antitoxic immunity.

THE RELATION OF ANAPITYLAXIS TO THE TOXEMIAS OF PREGNANCY

The symptoms of puerperal eclampsia and the conditions under which it occurs suggest that anaphylaxis may explain some of the mystery of this state. 
It occurred to us that either the blood or protein substance in solution from the fetus or the placenta may first sensitize the mother. A subsequent introduction into the system of the mother of a similar substance may explain the convulsions and the symptoms which occur in a certain class of the toxemias of pregnancy.

There seems to be a fair agreement that the placenta must be the source of the toxic material, especially as typical cases of eclampsia and pernicious vomiting have been observed in patients with hydatid mole in which cases, of course, toxic matter of fetal origin could be climinated. Furthermore, eclampsia may appear after the fetus has been remored. Much attention was therefore given to the hypothesis elaborated about four years ago by Veit, Weichardt and others that, through the entrance of placental cells into the circulation of the mother, an intoxication was caused either by disintegration of the cells and the formation of toxic substances or in the development of antisubstances by the maternal organism.

In spite of much experimentation and discussion, however, no satisfactory conclusions have ret been reached concerning the validity of this hypothesis and Martin has secured some very valuable evidence that, at least in rabbits, cntrance of their own placental elements into the circulation in large amounts does not cause any serious disturbance.

Along these lines we made a number of experiments to determine whether the fetal blood of the guinea-pig could sensitize the mother guinea-pig. We injected a number of female guinea-pigs, both pregnant and not prognant, with fetal blood and, after an appropriate interval, gave them a second injection of the same material. All these experiments resulted negatively, which was anticipated from our previous studies upon the effect of homologous blood serums. This is in harmony with the clinical observations that the poisons causing the toxemias of pregnancy do not come from the fetus.

We made a series of experiments on female guinea-pigs with guineapig placental extracts. The placenta (almost at full term) was ground up and allowed to autolyze about an hour at room temperature and some of the resulting extract was injected subcutancously into female guinea-pigs.

From cur studies it was evident that the mother guinea-pig may be sensitized with the autolytic products of her own placenta. These experiments naturally suggest that there may be a certain relation between some cases of puerperal eclampsia and the phenomenon in the guinea-pig which we are studying. Further studies along this line are now being made. 


\section{AN EXPLANATION OF THE PERIOD OF INCUBATION OF CERTAIN INFECTIONS}

The only plausible explanation of the period of incubation of an infectious disease heretofore considered has been that it required a certain time for the infective principle to grow in sufficient amount in the body to produce symptoms. This view is not tenable in many cases. The period of incubation in many cases is independent of the amount of infection.

In view of the studies on anaphylaxis we now have a more likely explanation of the period of incubation in certain cases. If the body is sensitized by the foreign protein dissolved out of the infecting organism it would require a certain definite time before the poisonous effects are felt. This not only explains why a certain time must elapse between the introduction of the infection and the onset of the disease, but gives us our first clew to the constancy of the period of incubation of certain maladies.

\section{ANTIBODIES}

We showed in our first publication in 1906 that the mechanism of anaphylaxis did not depend on an antibody free in the blood serum and body juices, as is the case in diphtheria and tetanus. In other words, this phenomenon is not simply a neutralization of a soluble poison by a soluble antipoison. There are antibodies other than free receptors which are readily demonstrable in vitro and in vivo. The definition of an antibody still lacks precision, and the action of these substances is not clearly understood. In this state of our knowledge it would be dogmatic to insist that the phenomenon of hypersusceptibility depends on the action of an antibody. The indications, however, seem to be that we are dealing with such an agent.

The anaphylactin readily demonstrable in the blood of a guinea-pig many months after the introduction of a minute fraction of a cubic centimeter of horse serum subcutaneously, can hardly be a portion or "rest" of the original minute amount of foreign protein injected. It seems probable that the introduction of the foreign protein stimulates or calls forth the production of anaphylactin, which flows free in the blood serum in relatively considerable amounts. There is evidence to indicate that anaphylactin is present in the blood serum in amounts greater than the amount of foreign protein originally introduced into the body.

We have shown that anaphylactin is present in the blood serum of immune guinea-pigs. This observation is very significant in this connection, for it indicates that the cells are protected despite the fact 
that they are continually bathed with the serum containing the sensitizing principle. The readiest explanation of this form of cellular immunity is the conception of a neutralizing antibody.

The further fact that hypersusceptibility, and not immunity to anaphylaxis, is transmitted from mother to young is another indication that we are dealing with an antibody.

Vaughan, Iewis, Nicolle, Besredka and most others-except Gay and Southard-who have studied this phase of the question consider an antibody necessary to explain the intimate nature of the phenomenon.

RELATION OF AXAPHYLAXIS TO PROTEIN METABOLISM

It is interesting to note that Ehrlich's explanation of antitoxic immunity was based on a chemical conception of protein metabolism. Ehrlich's haptophore side-chains that seize the toxin molecule have the same or similar affinities as those that seize and combine with the protein food molecule.

Another great conception of immunity, developed by Metchnikoff, is also clearly associated with protein metabolism or cellular digestion.

We now have another conception of immunity in certain infections based on the action caused by the introduction of a forcign protein into the body. This view is also closely bound up with the subject of protein metabolism. It can not but excite our wonder that the chemistry of the body should be so delicately balanced that the introduction of $1 / 10,000,000$ part of a gram of foreign protein should be able so profoundly to influence it as to result in serious symptoms when injected a second time.

The whole problem of protein metabolism seems to be an adjustment in the sense of a defense. The power to assimilate and use foreign proteins is not achieved without a certain amount of violence to the body. The relation between the fundamental facts of protein metabolism and the immunity to certain diseases becomes clearer in the light of observations upon anaphylaxis. Work on both these problems will throw light on the fundamental processes of each other.

\section{RELATION OF ANAPHYLAXIS TO ENDOTOXINS}

The fact that the great majority of bacteria do not produce soluble poisons such as diphtheria and tetanus has led to the belief that in such cases we are dealing with an "endotoxin." The endotoxin has long been regarded as a poisonous substance so intimately associated with the cell that it is not released until the microbic cell is broken up in the borly. The inability to demonstrate these endotoxins has cast 
a doubt on their existence and increased the mystery of their action. It now seems probable that the studies on anaphylaxis may throw light upon this question.

When bacteria grow in the body they are dissolved by lytic agencies and the foreign protein in the individual germ cells may sensitize the body and afterwards poison it. The bacterial proteins may not be poisonous in themselves in the sense of an "cndotoxin." We have, in fact, shown that protein extracts of bacterial cells at the first injection may produce characteristic symptoms, and this reaction may be followed by an immunity to the corresponding infection.

THE RELATION OF ANAPHYLAXIS TO TUBERCLLOSIS

The tuberculin reaction is one of the best known instances of anaphylaxis. Following a local infection with the tubercle bacillus the tissues generally become hypersusceptible to tuberculin. We have shown that a local hypersusceptibility may be produced by the direct application of tuberculin to certain tissues (conjunctiva). The same has been demonstrated for the skin, and is probably true of other tissues. This hypersusceptibility of the tissues immediately surrounding a tuberculous focus helps to encapsulate and limit the process. Should a tubercle bacillus lodge in or on a tissue in a state of tuberculin anaphylaxis the result is that all of Nature's protecting ageneies are quickly concentrated on the point where they are most needed. We conceive that this active power of reacting quickly is not only an important factor in individual prophylaxis against tuberculosis, but it is one of the important agencies which prevent the spread of the disease after it has obtained a lodgment in the body.

The normal individual does not react to tuberculin. The tuberculous individual reacts promptly, except in the final stage of the disease. The difference between the normal individual and the individual in the final stage of tuberculosis is that the former has not had his anaphylactic powers developed while the latter has had them developed and exhausted. A tuberculous individual in whom the specific power of hypersusceptibility to the poisons of the tubercle bacillus is broken down presents little or no resistance against the advance of the infection.

We may adduce a practical lesson from this: When tuberculin is used in large or too oft-repeated doses there is a tendency to break down or to exhaust the useful and beneficial hypersusceptible state of the tissues. In accordance with this line of reasoning, therefore, tuberculin would be of benefit in tuberculosis only when used in such 
a way as to levelop and not diminish the power of anaphylaxis of the tissues. This explanation has been borne out in the use of tuberculin.

While all of the views cxpressed here are based on experimental data, our interpretations of them may not all stand the test of time. It is evident, however, that studies on the subject of anaphylaxis give us a broader and deeper insight into some of the difficult and abstruse problems connected with both the recurrence of and the resistance to disease. The subject has proved a fruitful field for research. It has more than an academic interest. There is hope that a final solution of the mechanism of anaphylaxis will have a practical application in the treatment and prevention of a number of diseased states.

\section{BIBLIOGRAPHY}

1. Albrecht: Immunisierung gegen Heufieber durch Antitoxin und die biem Gebranche des letzteren beobachteten Falle von Anaphylaxie. Med. KKlin., Berl., 1908, No. 18.

2. Anderson (John F.): Transmission of resistance to diphtheria toxin by the female guinea-pig to her young. Jour. Med. Research, 1906, xv, 241.

3. Anderson (John F.) : Simultaneous transmission of resistance to diphtheria toxin and hypersusceptibility to horse serum by the female guinea-pig to her young. Jour. Med. Research, 1906, xv, 259.

4. Anderson (John F.) : I.-Maternal transmission of immunity to diphtheria toxin. II.-Maternal transmission of immunity to diphtheria toxin and hypersusceptibility to horse serum in the same animal. Bulletin 30, Hyg. Lab. U. S. P. H. and M.-H. S., 1906.

5. Anderson (John F.): The antiseptic and germicidal properties of solutions of formaldehyd and their action on toxins. Bull. 39, Hyg. Lab. U. S. P. H. and M.-H. S., July, 1907, 48 p.

6. Anderson (John F.) ; and Rosenau (M. J.): Further studies on anaphylaxis. Jour. Med. Research, 1908, xix, 37-66.

7. Arloing (S.): Cited by von Pirquet in Allergie, Ergebn. inn. Med. u. Kinderh., j, 1908.

8. Arthus (M.): Injections répétées de sérum de cheval chez le lapin. Compt. rend. Soc. biol., Paris, 1003, lv, 20.

9. Arthus (Maurice): Injeetions répétées de sérum de cheval chez le lapin. Compt. rend. Soc. biol., Paris, 1903, lv, 817 .

10. Bail: Ueberempfindlichkeit bei tuberkuliisen Tieren. Wien. klin. Wchnschr., 1904, p. 30.

11. Bail: Der akute Tod von Meerschwein an Tuberkulose. Wiener klin. Wehnschr., 1905, p. 15.

12. Banzhaf (Edwin J.), and Famulener (J. W.): A note on anaphylaxis. Proc. Soc. Exper. Biol. and Med., 1908, r, 62.

13. Beclère (A.), Chambon, and Menard: Etude expérimentelle des acciāents post-sérothérapiques. Ann. de l' Inst. Pasteur, 1896, x, 567.

14. Belfanti and Carbone: Produzione di sostanze tossiche nel siero di animali inoculati con sangue eterogeneo. Gior. d. r. Accad. di med., Torino, 1898.

15. Besredka (A.): Toxicité des sérums thérapeutiques, sa variabilité et son dosage. Ann. de l'Inst. Pasteur, Paris, 1907, xxi, 777.

16. Besredka (A.): Comment peut-on combattre l'anaphylaxie? Ann. de l'Inst. Pasteur, Paris, 1907, xxi, 950. 
17. Besredka (A.): De la toxicité des sérums thérapeutiques et du moyen de la doser. Compt. rend. Soc. de biol., 1907, lxii, 477.

18. Besredka (A.): Comment empecher l'anaphylaxie? Compt. rend. Soc. de biol., Paris, 1907, lxii, 1053.

19. Besredka (A.): Du mécanisme de l'anaphylaxie vis-à-vis du sérum de cheval. Tote préliminaire. Compt. rend. Soc. de biol., Paris, 1907, lxiii, $294-296$.

20. Besredka (A.): De l'anaphylaxie lactique. Compt. rend. Soc. de biol., Paris, 1908, lxiv, 888-889.

21. Besredka (A.): Du mécanisme de l'anaphylaxie vis-à-vis du sérum de cheval. Ann. de l'Inst. Pasteur, Paris, 1908, xxii, 496-50s.

22. Besredka (A.) and Steinhardt (Edna): De l'anaphylaxie et de l'antianaphylaxie vis-à-vis du sérum de cheval. Ann. de l'Inst. Pasteur, Paris, 1907, xxi, 117 .

23. Besredka (A.) and Steinhardt (Edna): Du mécanisme de l'antianaphylaxie. Ann. de l'Inst. Pasteur, Paris, 1907, xxi, 384.

23a. Besredka (A.) : De la vaccination antianaphylactique. Comp. Rend. Soc. Biol., Par., 1908, lxv, 478.

24. Bienenfeld (B.): Die Leukocyten in der Serumkrankheit. Mitt. d. Gesellsch. f. inn. Med. u. Kinderh. in Wien, 1907, vi, 5j.

25. Bienenfeld (Bianca): Das Verhalten der Leukozyten bei der Serumkrankheit. Jahrb. f. Kinderh. u. phys. Erziehung, 1907, lxv, 174.

26. Bier (A.): Beeinflussung bösartiger Geschwïlste durch Einspritzung von artfremdem Blut. Deutsch. med. Wehnschr., 1907, xxxiii, 1162.

27. Blain (Alexander W.): Urticaria following the second administration of diphtheria antitoxin. Med. Rec., 1908, lxxiii, 940.

28. Bligh (W.): Hypersensitization to antidiphtherial serum. Brit. Med. Jour., 1908, i, 501 .

29. Boone (E. L.): Sudden death following the use of diphtheria antitoxin. Jour. Am. Med. Assn., 1908, 1, 453.

30. Brieger: Weitere Erfahrungen ïber Bakteriengifte. Ztschr. f. Hyg., 1895,101 .

31. Bruch (A.): Accidents très graves consécutifs à l'administration préventive de sérum antidiphthérique chez un malade ayant reçu sans inconvenient huit ans auparavant une injection de sérum. Arch. de l'Inst. Pasteur de Tunis, 1908, No. 2, pp. 81-84.

32. Buttersack: Immunität und Heilung im Lichte der Physiologie und Biologie. Virchow's Arch. f. path. Anat., 1895, exlii, 248.

33. Cabannes (F.): Recherches au sujet de la toxicité des sérums hétérogènes. Compt. rend. Soc. biol,, Paris, 1907, lxii, 809.

34. Cheney (Henry W.): The serum disease. Illinois Med. Jour., 1907, xii, 248-253.

35. Coca (Arthur F.): The cause of suddden death following the intra. venous injection of the blood corpuscles of foreign species. Univ. Penn. Med. Bull., 1908, xxi, 243.

36. Courmont (Paul): Etudes sur les substances solubles prédisposantes à l'action pathogène de leurs microbes producteurs. Rev. de méd., 1891, x.

37. Courmont (Paul): Sur la toxicité à la clinique du Prof. Bondet et au laboratoire de M. Arloing. Arch. internat. de pharmacodyn. et thérap., 1900, vii, 281.

38. Courmont (Paul): De l'anaphylaxie avec les liquides de pleurésies tuberculeuses. (Essai d'explication de l'anaphylaxie.) Prov. méd., June 22, 1907 .

39. Currie (J. R.): On the supersensitization of persons suffering from diphtheria by repeated injections of horse serum. Jour. Hyg., 1907, vii, 35. 
40. Currie (J, R.) : Abnormal reactions to lorse serum in the serum treatment of cerebrospihal fever. Jour. Hyg., 1908, viii, 45i.

41. Dallera: Considerazioni e casi clinici di trasfusione del sangue. Morgagni, $18 \bar{\imath} 4$, vii.

42. Dehne and Hamburger (F.): Experimentelle Lntersuchungens über die Folgen parenteraler Einverliebung von Pferdeserum. Wien. klin. Welnschr., 1904 .

43. Detre-Deutsch: Superinfektion und Primäraffekt. Wien. klin. Wehnschr., 1904.

44. Detre (L.): [The serum disease.] Bör-esbyakórt, Budapest, 1907, p. $3-6 ; 25-28$.

45. DeWaele (H.) : La réaction à la tuberculine. Ann. Soc. de méd. de Gand., 1906, lxxiv, 84.

46. DeWaele (H.): Etude sur l'immunité conférée par la méthode des sacs de cellulose et sur les produits microbiens dialysants. Centralbl. f. Bakt., 1906, xlii, 636, 760 .

47. DeWaele (H.): Contribution à l'étude de l'anaphylaxie. Bull. Acad. roy. de méd. de Belge, $190 \bar{\tau}$, p. 715 .

48. Doerr (R.): Ceber Anaphylaxie. Wien. klin. Wchnschr., 1908, $\mathrm{xxi}, 415$.

49. Doerr (R.) and Baubitschek (H.): Toxin und anaphylaxirende Substanz des Heilserums. Berl. klin. Wehnschr., 1908, xxxiii, 3525.

50. Dogge (Charles A.): A case of sudden death after injection of antitoxin. Pediatries, 1896 , ii, 12 .

51. Francioni: Ta malattia da siero. La Sperimentale, 1904, 767 .

52. Francioni: Perlita dell' jmmunita passiva in seguito alla malattia da siero nella difterite. Riv. di clin. ped., 1907.

53. Friedemann (L.): Leber passive Ueberempfindlichkeit. München. med. Wchnschr., 1907, 2414.

54. Friedemann (I.) and Isaae (S.): Lieber Fiweissimmunitit und Eiweissstoffwechsel. /tsschr. f. exper. Path. u. Therap., $1905 \& 1906$.

55. Friedman (Ulrich) and Isaacs (S.): Weitere Untersuchungen äber den parenteralen Eiweissstoffwechsel, Immunitiit und Veberempfindlichkeit. Ztschr. f. exper. Path. u. Therap., 190\%, ir, 830.

56. Gabel (Wilhelm): Zwei Fälle ron Serumatosis (Serumkrankheiten). Centralbl. f. Kinderh., 1907, xii, 421.

57. Gay (Frederick P.) and Adler (Herman M.): The chemical separation of the sensitizing fraction (anaphylactin) from horse serum. Jour. Med. Research, 1908, xviii, 433.

58. Gay (F. P.j and Southard (E. E.): Serum anaphylaxis in the guineapig. Jour. Med. Research, 1907, xvi, 143.

59. Gay (Frederick P.) and Southard (Elmer E.): The mechanism of serum anaphylaxis and intoxication in the guinea-pig. Jour. Med. Research, 1908, xviii, 407.

60. Gay (Frederick P.) and Southard (Elmer E.): Recurrent anaphylaxis and repeated intoxication in guinea-pigs by means of horse serum. Jour. Med. Research, 1908, xix, I.

61. Gay (Frederick P.) and Southard (Elmer E.): The relative specificity of anaphylaxis. Jour. Med. Research, 1908, xix, 5.

62. Gay (Frederick P.) and Southard (Elmer E.): The localization of cell and tissue anaphylaxis in the guinea-pig, with observations on the cause of death in serum intoxication. Jour. Med. Research, 1908, xix, 17.

63. Gillette (Heibert F.): Diphtheria antitoxin in bronchial asthma. .Tour. Am. Med. Assn., 1908, 1, 40. 
64. Goodall (E. W.): The supersensitization of persons by horse serum. Jour. Hyg., 1907, vii, 607 .

65. Grunbaum (Albert S.) : Supersensitization to alien serum. Jour. Hyg., 1908, viii, $9-13$.

66. Hamburger (F.): Zur Frage der Inmunitaerung gegen Eiweiss. Wien. klin. Wehnschr., 1902.

67. Hamburger ( $F^{5}$ ): Arteigenheit und Assimilation. Vienna, Deuticke, 1904. 68. Hamburger (F.): Ueber Antitoxin und Eiweiss; experimentelle Studie. München. med. Wehnschr., 1907, liv, 254.

69. Hamburger (F.) and Moro (E.): Veber die biologiseh machweisbaren Veriinderungen des menschlichen Blutes nach Seruminjektion. Wien. klin. Wehnschr., 1903.

70. Hamburger (F.) and von Reuss: Die Folgen parenteraler Infektion von verschiedenen genuinen Eiweisskörpern. Wien. klin. Wchnschr., 1904.

71. Hamburger (F.) and von Reuss: Ueber die Wirkung artfremden genuinen Eiweisses auf die Leukocyten. Ztschr. f. Biol., 1905, xlvii, 24.

72. Hamman (Louis): The use and the value of tuberculin in the diagnosis of pulmonary tuberculosis. The Archives Int. Med., 1908, i, 443.

73. Hartung: Die Serumexantheme bei Diphtherie. Jahrb. f. Kinderh., 1896, xlii, 72 .

74. Heilner (Ernst): Ueber die Wirkung grosser Mengen artfremden Blutserums in Tierkorper nach Zufuhr per Os und subkutän. Ztschr. f. Biol., $190 \pi, 1,20$.

75. Heilner (E.): Ucber die Wirkung künstlich erzeugter physikalischer (osmotischer) Vorgänge im Tierkörper aud den Gesamtstoflumsatz mit Beriicksichtigung der Frage von der Uberemptfindlichkeit. Ztschr. f. Biol., 190 $\bar{i}, \mathrm{l}$.

76. Heim (P.) and John (K.): Allergie und Tuberkulinfiltratproben nach ron Pirquet-Detre. Wien. klin. Wchnschr., 1908, No. 8.

7. Hericourt (J.) and Richet (C.): Fffets lointains des injections de sérum d'anguille. Compt. rend. Soc. biol., Paris, Feb. 4, 1898, p. 137.

78. Johannessen (Axel): Teber Injektionen mit antidiphtherischem Serum ind reinem Pferdserum. Deutsch. med. Wehnschr., 1895, xxi, 855.

79. Kassowitz: Metabolismus und Immunität. Wien. med. Wehnschr., 1906.

79a. Kinyoun (J. J.): The toxic eftects of horse serum. Science, 1907, xxv, 810-811.

80. Kladnitski (N. N.): [Three cases of serum disease.] Vrach. gaz., St. Petersburg, 1906, xiii, 1353.

81. Klotz (Oscar): Sudden death following serum inoculations. Montreal Med. Jour., 1907, xxxvi, 615-618.

82. Knorr: Experimentelle Untersuchungen iiber die Grenzen der Heilungsmöglichkeit des Tetanus. Habilitationsschrift, Marbourg, 1895, 31 pp. 8 pls., 8 vo.

83. Krauss (V. R.) and Doerr (R.): Ueber Anaphylaxie. Centralbl. f. Bakteriol., 1908, xlii, 36.

84. Lehndorff: Serumkrankheit nach wiederholten Seruminjektionen. Monatsschr. f. Kinderh., 1906, iv.

85. Lemaire (Henri): Note sur quelques effets d'une injection de sérum antidiphtérique chez le lapin. Compt. rend. Soc. biol., Paris, 1906, 1x, 632.

86. Lemaire (H.): Recherches cliniques et expérimentales sur les accidents sérotoxiques. Thèse de Paris, 1906.

87. Lemaire (Henri): Recherches cliniques et expérimentales sur les accidents séro-toxiques. Paris, 1907 , roy. 8 ro, 160 p.

88. Iewis (Paul A.): The induced susceptibility of the guinea-pig to the toxic action of the blood serum of the horse. Jour. Exper. Med., 1908, x, 1-29. 
89. Lewis (Paul A.): Further observations on anaphylaxis to horse serum. Joux. Exper. Med., 1908, x, 608-617.

90. Löwenstein and Rappaport (E.): Leber den Mechanismus der Tuberkulinim unitit. Ztschr. f. Tuberk., 1904, vi, 566.

91. Mace (Lewis Sayre): The reaction of anaphylaxis. California State Jour. Med., 1908, vi, 174-176.

92. Magendie: Vorlesungen ïber das Blut., German translation by Krupp, 1839 ; cited by Ehrlich: Collected studies on immunitỵ, transl. by Charles Bolduan. New York, John Wiley, 1906, p. 332.

93. Marfan and Lemaire (H.): Contribution à l'étude des accidents sérotoxiques. L'erythème marginé aberıant. Rev. mens. d. mal. de l'enf., January, 1907 .

94. Marfan and LePlay: Recherches sur la pathogenie des accidents sérotherapiques. Soc. méd. d. hop., March 24 and May 19, 1905.

95. MeClintock and King: The oral administration of antitoxins for prevention of diphtheria, tetanus, and possibly sepsis, with some observations on the influence of certain drugs in preventing digestion and promoting absorption from the alimentary canal. Jour. Infect. Dis., 1906, iii, 700-720.

96. Moro (E.): Tuberculin reaction and the nervous system. Miunchen. med. Wchnschr., In08, Ir, 2025.

97. Much (II.): Ceber die antitoxische Funktion und Eiweiss. Muinchen. med. Mrehnschr., 1907, liv, 2589.

98. Netter (Arnold): Efficacité de l'ingestion de chlorure de calcium comme moven preventif des éruptions consecutives aux injections de sérum: Compt. renil. Soc. de biol., Paris, 1906, lx, 279.

99. Netter (Arnold): Influence des quantities de sérum injectées et du nombre des injections sur les éruptions sériques. Compt. rend. Soc. de biol.; Paris, 1906, 1x, 281.

100. Nicolle (Maurice) : Contribution a l'étude du "phênomêne d'Arthus." Ann. de l'Inst. Pasteur, Paris, $190 \bar{i}$, xxi, 128.

101. Nicolle (M.): Une conception générale des anticorps et de leurs efiets. Compt. rend. Soc. de biol., Paris, 190 7 , lxiii, 77 .

102. Nicolle (M.) and Pozerski (E.): Les anticorps des toxines solubles; Nicolle (M.) and Abt: Les anticorps des albuminöides et des cellules. Nicolle (M.): Jes anticorps normaux. Ann. de l'Inst. Pasteur, 1908, xxii.

103. Ohlmacher (A. P.): The reaction of hypersusceptibility as produced by bacterial inoculations. Jour. Med. Research, July, 1908, xix, 113.

104. Otto (R.): Das Theobald Smith'sche phänomen der Serum-Leberempfindlichkeit. Von Leuthold Gedenkschrift, 1905, i.

105. Otto (R.): Zur Frage Serum-Leberempfindlichkeit. München. med. Wchnschr., 1907, liv, 1665 .

106. Otto (R.): Ueber Anaplyylaxie und Serumkrankheit, im besonderen iiber experimentelle Serum-Uberempfindlichkeit. Handbuch der patho. Mikroorganismen, by Kolle and Wassermann, 1908, ii, 255.

107. Park (Wm. H.): The effects on man of injections of lorse serum; serum sickness. Harvey Lecture. Philadelphia and London, 1906, p. 107.

108. Pfeiffer (Hermann): Eeber die nekrotisierende Wirkung normaler Serum. Wien. klin. Wchnschr., 1905, xviii, p. 465.

109. Portier and Richet (C.): De l'action anaphylactique de certains venins. Compt. rend. Soc. biol., Paris, 1902, lxiv, 170.

110. Pozerski (E.): Anaphylaxie du cobaye pour la papaine. Compt. rencl. Soc. de biol., Paris, 1908, kiv, 631-632.

111. Preisich (K.) and Heim (P.): Ueber das Wesen der Tuberkulinre. aktion. Centralbl. f, Bakteriol., 1902, xxxi, 681. 
112. Quigley (James Knight): Collapse after the use of diphtheria antitoxin. Jour. Am. Med. Assn., 1908, 1, 768.

113. Remlinger (P.): Absence d'anaphylaxie au cours des injections souscutanées de virus rabique et de serum antirabique. Compt. rend. Soc. de biol., Paris, 1906, lxi, 475-476.

114. Remlinger (P.): Contribution a l'êtude du phénomène d'anaphylaxie. Compt. rend. Soc. de biol., Paris, 1907, $1 \times 1 i, 23-25$.

115. Remlinger (P.): Absence d'anaphylaxie à la suite d'injections souscutanées de substance nerveuse. Compt. rend. Soc. de biol., Paris, 1908, lxiv, $641-645$.

116. Richet (C.): De l'anaphylaxie, ou sensibilité croisante des organismes à des doses successives de poison. Arch. di fisiol., 1904, i, 129.

117. Richet (C.): De l'action de la congestine (virus des actines) sur les lapins et des effets anaphylactiques. Compt. rend. Soc. biol., Paris, 1905, lviii, 109 .

118. Richet (C.): De l'anaphylactique après injections des congestine, chez le chien. Compt. rend. Soc. biol., Paris, 1905, lviii, 112.

119. Richet (C.): Anaphylaxie par injections d'apomorphine. Compt. rend. Soc. biol., 1905, lviii, 955 .

120. Richet (C.): Anaphylaxie par la mytile-congestine. Compt. rend. Soc. de biol., Paris, 1907, lxii, 358-368.

121. Richet (C.) : Mésure de l'anaphylaxie par la dose êmétisante. Compt. rend. Soc. biol., Paris, 1907, lxii, 643.

122. Richet (Charles): De l'anaphylaxie en général et de l'anaphylaxie par la mytilo-congestine en particulier. Ann. de l'Inst. Pasteur, Paris, 1907, xxi, 497 .

123. Richet (C.): De l'anaphylaxie et des toxogénines. Ann. de l'Inst. Pasteur, Paris, 1908, xxii, 465.

124. Richet (Charles): De la substance anaphylactisante du toxogénine. Compt. rend. Soc. de biol., Paris, 1908, 1xiv, 846-848.

125. Richet (C.): Note sur l'anaphylaxie. Des propriêtés différentes dissociables par la chaleur d'une substance toxique. Compt. rend. Soc. biol., Paris, 1908, lxy, 404. 404.

126. Richet (C.) : Note sur l'anaphylaxie. Comp. Rend. Soc. Biol., 1908, Ixv,

127. Rosenau (M. J.) and Anderson (John F.): A study of the cause of sudden death following the injection of horse serum. Bull. 29 Hyg. Iab. U. S. P. H. and M.-H. S., 1906.

128. Rosenau (M. J.) and Anderson (John F.): A new toxic action of horse serum. Jour. Med. Research, 1906, xv, 179.

129. Rosenau (M. J.) and Anderson (John F.): Hypersusceptibility. Jour. Am. Med. Assn., 1906, xlvii, 1007.

130. Rosenau (M. J.) and Anderson (John F.): Studies on hypersusceptibility and immunity. Bull. $36 \mathrm{Hyg}$. Lab. (T. S. P. H. and M.H. S., April, 1907.

131. Rosenau (M. J.) and Anderson (John F.): Further studies on hypersusceptibility and immunity. Jour. Med. Research, 1907, xvi, 381.

132. Rosenau (M. J.) and Anderson (John F.): The specific nature of anaphylaxis. Jour. Infec. Dis., 1907, iv, 552.

133. Rosenau (M. J.) and Anderson (John F.): Anaphylaxis. Reference handbook of medical sciences, 1908 , viii, 353.

134. Rosenau (M. J.) and Anderson (John F.): A review of anaphylaxis with especial reference to immunity. Jour. Infect. Dis., 1908, v, 85.

135. Rosenau (M. J.) and Anderson (John F.): The relation of anaphylaxis to the toxemias of pregnancy. Tr. Assn. Am. Phys., 1908, xxiii. 
136. Rosenau (M. J.) and Anderson (John F.): Further studies on anaphylaxis. Bull. 45 Hyg. Jab. U. S. P. H. and M.-H. S., June, 1908.

137. Rosenhaupt (H.) : Klinischer Beitrage zur Serumkrankheit. Mïnchen. med. Wehnschr., 1905, lii, 2019.

138. Rovere: Sur la présence de précipitines dans le sang de sujets atteints d'accidents consécutifs à des injections de sérum antidiphthérique. Arch. gén. de méd., 1906, vi.

139. Saeli: Sulle fine alterazioni di struttura degli organi per injezioni di siero di sangue eterogene. Rif. med., 1905.

140. Salge: Einige Bemerkungen zu dem Thema "Arteigenes und artfremdes Eiweiss" in bozug auf die Säulingsernährung. Monatschr. f. Kinderh., August, 1906.

141. Saward: Syncope occurring after injection of antitoxin in cases of diphtheria. Brit. Med. Jour., 1902, i, 1025.

142. Schick (B.): Kutan-Reaktion bei Impfung mit Diphtherietoxin. München. med. Wehnschr., 1908, lv, 504.

143. Schofield (Alfred T.): A case of egg poisoning. Lancet, London, 1908, elxxiv, 716 .

144. Shibayama: Ueber die Wirkung der bakteriologischen Heilsera bei wiederholten Injektionen. Centralbl. f. Bakteriol., 1906, xli, 571.

145. Stadelmann and Wolft-Eisner: Ueber Typhus und Kolisepsis und über Typhus als Endotoxinkrankheit. München. med. Wchnschr., 1907, liv, 1161, 1237. 146. Thorne (R. Thorne): Hypersensitiveness to antidiphtheric serum. Brit. Med. Jour., 1908, i, 147.

147. Torkomian: Maladie du sérum. Ga\% méd. d'orient, 1906, li, 162.

148. Uhlenhuth: Zur Kenntniss der giftigen Eigenschaften des Blutserums. Ztschr. f. Hyg., 1897, xxvi, 384 .

149. Vasconcellos (F.): Anaphylaxia. Two brochures of 9 and 20 pages from the Institut de Manguinhos. Rio de Janeiro, 1907.

150. Vaughan (V. C.): Discussion of Rosenau and Anderson's paper on Hypersusceptibility, Jour. Am. Med. Assn., 1906, xlvii, 1009.

15l. Vaughan (Victor C.): Hypersusceptibility and immunity. Science, 1908, xxvii, 644 .

152. Vaughan (Victor C.) and Wheeler (Sybil May): The effects of eggwhite and its split products on animals. A study of susceptibility and immunity. Tr. Assn. Am. Phys., 1907, xxii, 268. Jour. Infec. Dis., 1907, iv, 476.

153. Von Behring (E.) and Kitashima (S.): Ueber Verminderung und Steigerung der ererbten Giftempfindlichkeit. Berl. klin. Wchnschr., 1901, 157. 154. Von Pirquet (C.): Zur Theorie der Infektionskrankheiten. Vorlïufige Mitteilung, April 2, 1903. Veröflentl. d. k. Akad. d. Wissensch. Wien, Feb. $13,1908$.

155. Von Pirquet (C.): Allergie. München. med. Vehnschr., 1906, No. 30. 156. Von Pirquet (C.): Ist dic Vakzinale Friihreaktion specifisch? Wiener klin. Woch., 1906, xix, No. 47.

157. Von Pirquet (C.): Die fruihzeitige Reaktion bei der Schutzpockenimpfung. Wien. klin. Wehnschr., 1906, xix, 28.

158. Von Pirquet (C.): Die cutïne Tuberkulin probe. Med. Klin., 1907. Verhandl. d. Gesellsch. f. Kinderh., 1907.

159. Von Pirquet (C.): Tuberkulindiagnose durch cutaine Impfung. Berl. klin. Wehnschr., 1907.

160. Von Pirquet (C.): Der diagnostische Wert der cutänen Tuberkulinreaktion auf Grund von 100 Sektionen. Wien. klin. Welınschr., 1907.

161. Von Pirquet (C.): Die Allergieprobe zur Diagnose der Tuberkulose im Kindesalter. Wien. med. Wchnschr., 1907, No. 28. 
162. Von Pirquet (C.): Allergie-Diagnostik. Therap. Monatsh, November, 1907 .

163. Von Pirquet (C.): Klinische Studien über Vakzination und vakzinais Allergie. Leipzig, Franz Deuticke, 1907, 194 p.

164. Von Pirquet (C.): Cutäne und conjunctivale Tuberkulinreaktion. Handbuch Kraus \& Levaditi, 1908.

165. Von Pirquet (C.): Zur Diskussion über die cutine und conjunctivale Tuberkulinreaktion. Berl. klin. Woch., 1908, No. 9.

166. Ton Pirquet (C.): Allergie. Ergebnd inn. Med. u. Kinderh., Julius Springer, Berlin, 1908.

I67. Von Pirquet (C.) and Sehick (B.): Zur Theorie der Inkubationszeit. (Vorläufige Mitteilung.) Wien. klin. Wehnschr,, 1903, No. 45.

168. Von Pirquet (C.) and Schick (B.): Zur Theorie der Inkubationszeit. Wien. klin. Wehnschr., 1903, No. 45.

169. Von Pirquet (C.) and Schick (B.): Zur Frage der Aggressins. Wien. klin. Wchnschr., 1905.

170. Von Pirquet (C.) and Schick (B.): Die Serumkrankheit. Leipsic, Franz Deuticke, 1905, 144 pp.

171. Wassermann (A.): Wesen der Infektion. Kolle \& Wassermann's Handbuch der pathogenscher Mikroorgamsmen, 1903, i, 223.

172. Wassermann (A.) and Bruck (C.): Experimentelle Studien über Wirkung von Tuberkelbacillenpräparaten auf den tuberkulös erkrankheiten Organismus. Deutsch. med. Wehnschr., 1906, xxxii, 449.

173. Wassermann (A.) and Citron (J.): Die lokale Immunitiit der Gewebe und ihre praktische Wichtigkeit. Deutsch. med. Wchnschr., 1905, xxxi, 573.

174. Waterhouse (Rupert): Hypersensitization to antidiphtherial serum. Brit. Med. Jour., 1908, i, 925-926.

175. Weil-Halle (B.) and Lemaire (H.): Quelques conditions de l'anaphylaxie sérique passive chez le lapin et le cobaye. Compt. rend. Soc. de biol., Paris, 1907, lxiii, 748-750.

176. Weil-Halle und Lemaire (Henri): L'anaphylaxie passive du cobaye pour le serum de cheval. Compt. rend. Soc. de biol., Paris, 1908, lxr, 141-142.

177. Wells (H. Gideon): The nature of the poisonous element of proteins that is concerned in the reaction of hypersensitization. Jour. Am. Med. Assn., 1908, I, 527-528.

178. Wells (H. Gideon): Studies on the chemistry of anaphylaxis. Jour. Infect. Dis., 1908, v, 449-483.

179. Wolff-Eisner (A.): Ueber Grundgesetze der Tmmunitït. Ztschr. f. Bakteriol., 1904. Berl. klin. Wchnschr., 1904, xli. 1105, 1131, 1156, 1273.

180. Wolf-Eisner (A.): Ueber die Urticaria vom Standpunkte der neuen Erfahrungen. Dermat. Zentralbl., 1906, x.

181. Wolff-Eisner (A.): Das Heufieber, sein Wesen und seine Bedeutung. München, J. F. Lehmann, 1906.

182. Wolff-Jisner (A.): Die Endotoxinlehre. München med. Wchnschr, 1906, liii, 217.

183. Wolff-Eisner (Alfred): Leber Eiweissimmunitat und ihre Beziehungen zur Serumkrankheit. Centralbl. f. Bakteriol., 1906, xl, 378.

184. Wolff-Eisner (A.): Typhustoxin, Typhusantitoxin und Typhusendotoxin. Die Beziehungen zwischen Uberempfindlichkeit und Immunitit. Berl. klin. Wehnschr., 190i, xliv. 